Article

\title{
Assessment of the Industrial Structure and its Influence on Sustainable Economic Development and Quality of Life of the Population of Different World Countries
}

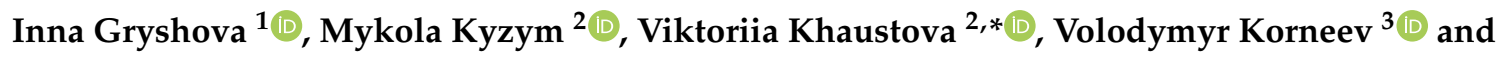 \\ Hennadii Kramarev ${ }^{2}$ \\ 1 Jiangsu Normal University, 101 Shanghai Rd, Tongshan Qu, Xuzhou 221100, China; 6020180146@jsnu.edu.cn \\ 2 National Academy of Sciences of Ukraine, Research Centre of Industrial Problems of Development, 1a \\ Inzhenernyi Ln., 61166 Kharkiv, Ukraine; m.kyzym@gmail.com (M.K.); khamhen@ukr.net (H.K.) \\ 3 Ministry of Economic Development and Trade of Ukraine, State Research Institute of Informatization and \\ Modeling of Economy, 38 Druzhby narodiv Boul., 01014 Kyiv, Ukraine; vkorn27@gmail.com \\ * Correspondence: v.khaust@gmail.com; Tel.: +38-0503250180
}

Received: 15 January 2020; Accepted: 24 February 2020; Published: 8 March 2020

check for updates

\begin{abstract}
The article proves that despite a significant growth in the service sector in recent years, industry remains the main engine of economic growth. Moreover, using the analysis of statistical data, it is shown that the development of industrial complexes of countries of the world is accompanied by corresponding structural changes, which in turn determines their economic development in general. The study aims to solve the following issues: which structure of the national industry can be considered progressive under modern conditions, i.e., can lead to progress and sustainable socio-economic growth; whether there is a correlation between the progressive structure of the country's industry and its economic development and the quality of life of its population; how the approach of the country's industrial structure to its progressive state influences the country's economic development and quality of life of its population. The purpose of the study is to justify or refute the hypothesis about influence of progressiveness of the industrial structure on sustainable economic development and quality of life of the population. The main methods used in the study are cluster analysis and integral assessment. The statistical basis of the study is the data on inter-branch balances for 36 countries of the world for 2009, 2011 and 2014. The results obtained in the study allowed confirming the hypothesis about the positive influence of approach of the industrial structure of countries of the world to its progressive state on the sustainable economic development and quality of life of their population. This conclusion can be considered as the basis for forming the state policy of the world's countries to develop their economies and improve the quality of life of their population.
\end{abstract}

Keywords: industrial structure; structural changes; sustainable economic development; quality of life of the population; Gross Value Added; progressiveness; technological level; manufacturing industry; engineering

\section{Introduction}

\subsection{The Role of Industry in the Sustainable Economic Growth of Countries of the World}

At present, scientists continue carrying out discussions about the role of industry in economic growth of countries of the world. One group of scientists believes that the services sector provides the greatest productivity growth in the modern economy, while others believe that industry is the basis and engine of economic growth. 
For example, according to Jorgenson and Timmer (2011) [1], services currently account for about three quarters of the total value added, and it is they that provide the productivity growth in the US and Japan.

At the same time, Rodrik (2013) [2] demonstrates that there is convergence in labor productivity in manufacturing-meaning that countries with a higher share of manufacturing exhibit higher growth rates-and thus proves that industry itself is an engine of growth.

A thorough analysis and systematization of scientists' work on problems of economic growth and industrialization, where the manufacturing sector plays an important role as a growth engine, is presented in Rocha's work (2018) [3]. According to the author, theoretical, historical and empirical evidences have shown the importance of manufacturing to sustained economic growth.

According to Rocha, based on the hypothesis that industrial structure influences both the rate and direction of economic development, the achievements of the structuralist literature prove the importance of industrialization as a process of structural change, where the manufacturing sector plays a central role. In this case, economic development is provided through redistribution of production from low-productivity sectors to high-productivity ones.

As the world practice shows, the growing trend of industrial fragmentation in the world not only reduced the share of production in many economies but also had a negative impact on these countries due to the deterioration in so-called industrial associations, which resulted in the loss of high value-added activities (e.g., R\&D) and the ability to generate technological innovations [3]. This once again emphasizes the important role of the manufacturing sector as a locus of technological change since the first industrial revolution. Having studied various theories of economic growth, Rocha proved that manufacturing has some special properties that are not found in other industries, and is very important for sustainable development. Similar findings were also obtained in studies $[4,5]$.

The importance of the manufacturing sector to ensure sustainable economic growth is emphasized in a note by the UNCTAD secretariat, which states, "Economic diversification and structural transformation, towards a greater reliance on manufacturing as a share in the total output and employment of economies, have been synonymous with development" [6]. Development of manufacturing provides productivity gains and, at the same time, employment and income opportunities. Due to this unique characteristic of the sector, Governments promote economic diversification and structural changes aimed at development of manufacturing through a number of measures, in particular through implementation of various forms of industrial policy [6].

Thus, there are still valid arguments proving that despite a significant growth in the service sector in recent years, industry remains the main engine of growth, accumulates achievements of the scientific and technological progress and is a conductor of the innovation development of the national economy.

At the same time, as the statistics shows, development of industrial complexes of the world countries goes on in cycles with periodical changes of the structure under the influence of actions of many internal and external factors.

The analysis of the data of inter-branch balances for 36 countries of the world showed that the Gross Value Added (GVA) of the industry in 2014 took $22.0 \%$ in the general volume of GVA of their economies (see Table A1 Appendix A [7]).

As we can see from Table A1, the following countries had the largest volume of the GVA of industry: China-USD 3,771,566.3 million, United States-USD 2,980,338.0 million, Japan-USD 922,796.7 million, Germany-USD 865,107.9 million and Russia-USD 441,091.9 million, while the following ones had the smallest volume: Latvia-USD 4,310.7 million, Estonia-USD 4,723.8 million and Lithuania-USD 8,832.4 million.

The following countries had the largest specific weights of the GVA of the industry in 2014: China-36.7\%, South Korea-33.7\%, Czech Republic-30.8\%, Russia-27.2\% and Mexico-26.3\%, while the smallest ones: Greece-14.4\%, France-12.8\% and Great Britain-14.4\%.

At the same time, the data of the studied countries testify to the fact that the total volume of the GVA of the industry in these countries increased from USD 9,116,851.4 million in 2009 up to USD 
$13,330,371.0$ million in 2014 , that is by $146.2 \%$, which testifies to a significant increase in the contribution of the industry into the added value of the countries.

Besides, the following countries had the biggest rates of growth of the GVA of the industry from 2009 until 2014: South Korea-203.4\%, China-200. 3\%, Estonia-156.2\%, Sweden-154.7\% and Russia-153.0\%. Only three countries had a reduction of the rates of the industrial GVA growth: Ukraine, Japan and Greece.

The complexity and ambiguity of the interrelations of these processes, their dependence on current trends (the digitalization of the economy, spread of production automation, development of new technologies, etc.) determine the unquenchable interest of scientists and practitioners in issues related to structural changes and their impact on the economic growth of countries of the world.

\subsection{The Connection Between Structural Changes in the Economy (Industry) of Countries and Their Sustainable Economic Growth}

Thus, as the conducted analysis shows, that the development of industry in countries of the world is characterized by various trends that are reflected in changes in the economic (industrial) structure and determine economic development of countries in general.

It is worth mentioning that economic theory pays considerable attention to the problems of analyzing economic structure and structural changes.

The fact that economic growth cannot proceed without structural change was formulated by Schumpeter in 1934 [8]. However, the beginning of fundamental research on economic structure dates back to the first half of the 20th century and is associated with the works of Fischer (1935) [9], Clark (1940) [10] and Fóurastié (1954) [11]. The scientists laid the theoretical principles of structural change in the economy using a three-sector model (the hypothesis of three sectors), which describes the evolution of the economy from agricultural and industrial economic structures to the sphere of services.

In the 1950s, in parallel with studying the three-sector hypothesis, interest in considering structural changes as a factor of economic growth intensified. The development of this research area was preceded by the works of Rosenstein-Rodan (1943) [12] and Nurkse (1953) [13], who justified the need to combine differences of industries as a condition for balanced growth.

Further theoretical treatment of this problem is highlighted in the works of the Nobel laureate Lewis (1954) [14] and later on Ranis and Fei (1961) [15]. Lewis's study [14] was built upon the assumption that most countries had economies based on the agricultural and industrial sectors. At the same time, the agricultural sector was characterized by low productivity, low incomes and savings, as well as significant underemployment. The industrial sector was defined by the scientist as technologically advanced and with a high level of investment.

The structural transformations that take place in processes of countries' development are studied, among others, in works of a number of authors: Chenery and Watanabe (1958) [16], Hirschman (1958) [17], Hoffmann (1958) [18], Kuznets (1966) [19], Todaro (1969) [20,21], Chenery and Syrquin $(1975,1979)[22,23]$, Ishikawa (1987) [24]. These studies highlight the structural characteristics of growth, patterns of structural change, and phenomenology of economic development.

It should be pointed out that attention to structural transformations in the economy is not diminished in modern scientific research. Presently, an increasing number of scholars consider the relationship between structural change in countries of the world and their economic development in their works.

An analysis of the impact of structural changes on national economies is carried out in the works of Raiser, Schaffer and Schuchhardt (2003) [25], Thießen and Gregory (2005) [26], Kyzym and Milyutin (2017) [27], Gryshova et al. (2019) [28].

Beg, Sertic and Druzic (2017) [29] analyze the differences in structural changes in the economies of $26 \mathrm{EU}$ member states in the process of deindustrialization for the period 1995-2012 and compare factors of deindustrialization in post-communist economies and developed European countries. 
The research of Dudzevičiūte et al. (2014) [30] deals with identifying features of structural changes in the Lithuanian economy and their assessment in a global context. The research methodology is based on the use of the classical three-sector model (agriculture, industry and the sphere of services) and methods for assessment of structural changes and comparative analysis of statistical data on economic structures.

It should be noted that analysis of the economic structure of different countries and its transformations in the context of the three main sectors is widely used in modern research (e.g., Teigeiro and Solis (2007) [31]; Alba (2010) [32]; Jiang (2011) [33]; Mao Yao (2012) [34]; Zdrazil, Kraftova and Mateja (2016) [35]). Also, a number of scientists study economic structure in the context of individual sectors and economic activities (e.g., Tanuwidjaja and Thangavelu (2007) [36]; Matsuyama (2009) [37]; Kokocinska and Puziak (2009) [38], Cho, Cho and Lee (2013) [39], Zdrazil, Kraftova and Mateja (2016) [35], Gryshova et al. [40]).

Based on the calculations made, Dudzevičiūte et al. (2014) [30] determined that, during the last decade, the agricultural and industrial sectors of the Lithuanian economy were growing more slowly, and the structure of the global economy changed to the economic structure based on services. The authors also made an attempt to compare the structural shift in the Lithuanian industry with the average indicators for Asia, Europe and the world. The scientists found out that it was close to the North American and Oceania average by the contribution to the total value added. Over a period of 1990-1995, the Lithuanian industrial sector contribution to the total economy was growing, while it was decreasing in Europe, Asia and other regions of the world. At the same period of time, the process of tertiarization was apparent in the global economy and the Lithuanian service sector growth was twice faster than the European and Asian countries' average [14].

Article Noguera-Méndez, Semitiel-García and Lypez-Martínez (2016) [41] deals with analysis of structural changes in the economies of countries taking into account the per capita income. In this study, the authors study inter-branch structures at the national level by applying traditional input-output measures as well as network analysis. However, the authors focus mainly on inter-branch structures as a main explanatory factor of the observed international disparities in development. Based on the results of the study, the authors conclude that there is a fundamental inter-branch structure, common to all countries, and at the same time there exist structural differences that correspond to differences in the levels of development, industrial specialization, structural position of some branches and course uneven development of countries.

Kamaruddin and Masron' work (2010) [42] deals with the structural changes and sources of growth in the manufacturing sector in Malaysia. The authors conclude that export is becoming an increasingly important factor in changes in the structure of industrial growth of the Malaysian economy, and structural changes in the country's economy are mainly caused by the reorientation of industrialization strategies as well as changes in relation to the domestic demand.

Tanuwidjaja and Thangavelu (2007) [36] analyze the relationship between the structural changes and productivity of the manufacturing sector of the Japanese economy. They classify manufacturing industries into four sectors according to the technological degree. The paper reveals that the productivity was most notably in the medium-high-technology sector, which resulted from the structural change that occurred in the late 1990s.

Olczyk and Kordalska (2018) [43] examine the relationship between structural changes (changes in Gross Value Added and employment) and economic growth.

Zdrazil, Kraftova and Mateja (2016) [35] draw attention to the correlation between innovation capacity and industrial structure of economies. Their work is aimed at investigating whether selected groups of European countries show similar trends in industrial structure development reflected in its innovative capacity.

Thus, the interest of scientists in the problems of assessing structural changes in the economy (industry) and their impact on the economic development of countries of the world is manifested in intensification of research in this area. At the same time, noting the existence of a connection between 
these structural changes and economic growth, scientists use different approaches and methods for their analysis, different statistical basis. At the same time, structural changes and the corresponding structural policy are considered both as a consequence and a source of economic growth.

Noting the existence of a connection between structural changes and the country's economic growth, scientists use different approaches and methods of their analysis, different statistical basis. When considering structural changes, industry is most often analyzed with the application of a 3-sector model as well as by individual sectors and types of economic activity (TEA), the approaches being used are input-output analyses, network analysis, etc.1.3. The key issues and the hypothesis of the research Today, the problem of ensuring sustainable socio-economic development is a key one for most countries of the world. At the same time, modern realities necessitate the provision of such economic growth that would be sustainable in the broad sense (i.e., stable, progressive in the long run and environmentally sustainable at the same time). This means that the process of growth should have a well-thought-out basis and cover those economic sectors that can ensure it.

The above review allowed to reveal that the intensive processes of structural transformations of the economies (and industrial systems) of countries, which are going on in the world, are accompanied by an increase in the unevenness of their development and determine the sources and resources for their economic growth. Under these conditions, the governments of countries of the world are forced to seek modern effective directions of structural and industrial policy. This, on the one hand, would ensure sustainable economic growth of the country and the corresponding quality of life of its population, and, on the other hand, use the potential of digital technologies for economic diversification, positive structural transformations and increase in the value added.

Thereby, in our opinion, a number of issues require further research, namely:

which structure of the national industry under current economic conditions can be considered progressive, i.e., can lead to progress and sustainable socio-economic growth;

whether there is a correlation between the progressive structure of a country's industry and its economic development and the quality of life of its population (which is a complex indicator of the national socio-economic development);

how the approach of the country's industrial structure to its progressive state influences the country's economic development and the quality of life of its population.

An attempt to resolve these issues was made in this study, its main hypothesis being formulated as follows: progressiveness of the industrial structure of the country influences the economic growth and quality of life of its population.

The presented study is aimed at further development of knowledge about the influence of structural and industrial policies on the socio-economic development of countries of the world.

\section{Materials and Methods}

The goal of this study is justification or refutation of the hypothesis about influence of the progressiveness of the industrial structure on the sustainable economic development and quality of life of the population of the world countries.

The following study tasks were specified in order to achieve the set goal:

Establishing the theoretical bases for analysis and evaluation of industrial structure.

Justifying criteria of progressiveness of the industrial structure and calculating averaged values of the criteria of progressiveness on the basis of analysis of the industrial structures of the leading countries of the world.

Studying how the approach of the country's industrial structure to its progressive state influences the country's economic development and quality of life of its population (using cluster analysis).

Performing integral assessment of correspondence of the industrial structure of the world countries with its progressive state (with the help of the integral indicator). 
Studying how the integral indicator of correspondence of the industrial structure with its progressive state influences the quality of life of the population and the industrial GVA volume per capita (using cluster analysis) and justify or refute the stated hypothesis of the study.

The data of inter-branch balances for 36 countries of the world were the base selection of the study of the industrial structure of the world countries and its influence on the economic development and quality of life of their population (WIOD base) [7]. Countries were selected on the basis of their industrial GVA volumes. Besides, the list includes both developed countries and the most successful developing countries.

The last 2016 release of World Input-Output Tables and underlying data cover 43 countries and a model for the rest of the world for the period 2000-2014. There is a lag of about 2 years to develop an input-output table (or supply and use table) by national statistics bureaus, and another 2 years are needed to develop international input-output tables on the basis of the national statistical data of the System of National Accounts (SNA) and international trade statistics (UNCTAD). Moreover, in some countries, the national input-output tables are not developed annually but once every two years (in Great Britain from 2010 till 2014) or even once every five years (Republic of Bulgaria).

Thereby, the most recent study period was the year 2014 due to periodicity and features of formation of inter-branch balances of the world countries.

With regard to the tasks set in the study, the following methods were used:

For establishing the theoretical bases for analysis and evaluation of the industrial structure, in particular: defining the essence of the basic concepts that have to do the industry structure; identifying the existing approaches to the analysis of the economic (industrial) structure; forming a classification of the country's industrial sectors which would be used for studying the industrial structure of the world's countries; justifying the criteria of progressiveness of the industrial structure-general scientific methods: analysis and synthesis, generalization, content analysis of literary sources.

For calculating the averaged values of the criteria of progressivity on the basis of analysis of the industrial structures of the leading countries of the world-methods of grouping and classification, averaging.

For assessing the correspondence of the industrial structure of the world countries with its progressive state-method for calculating the integral indicator.

For evaluating the influence of approach of the industrial structure of the country to its progressive state on the economic development and quality of life of its population—cluster analysis.

The general design of the research is presented in Table 1.

Thus, the research comprises four main parts.

The first part deals with the formation of the theoretical bases of the study. It involves analysis of the scientific developments related to the studied problems and is aimed at justifying, based on the results of the analysis, the criteria and approaches to assessing progressiveness of the industrial structure of countries.

The second part implies calculating the progressive values of the industrial structure by various criteria (various sectoral divisions of the industry) and assessing on this basis the progressiveness of the industrial structure of the studied sample of the world countries. Since this part of the study is aimed at determining the average values of the criteria of progressiveness using analysis of the production structures of the world countries, its main methods used are: grouping and classification, averaging. The input data for the analysis of production structures of the world countries are the data of inter-branch balances for 36 countries (WIOD) [7], which, as was considered in Introduction, are widely used in such studies. 
Table 1. Research design.

\begin{tabular}{|c|c|c|}
\hline $\begin{array}{l}\text { Stage } \\
\text { S }\end{array}$ & Basic Procedures & Materials and Methods \\
\hline $\begin{array}{l}\text { 1. Generalization of the theoretical bases for analysis } \\
\text { and evaluation of industrial structure }\end{array}$ & $\begin{array}{l}\text { 1.1. Clarifying the interpretation of the concept "industrial structure of the country" } \\
\text { 1.2. Classifying sectors of the country's industry by the main features (by processing } \\
\text { depth- - -sector by technological level, by types of economic activity) which characterize its } \\
\text { structure and are the basis for its further analysis } \\
\text { 1.3. Justifying the interpretation of the concept "progressive industrial structure" as the one } \\
\text { most clearly reflecting the goals of industrial development } \\
\text { 1.4. Analyzing the criteria of progressiveness of the industrial structure and approaches to } \\
\text { calculating their values }\end{array}$ & $\begin{array}{l}\text { Methods: content analysis of literary sources; general scientific methods-analysis } \\
\text { and synthesis, generalization } \\
\text { Analytical basis: scientific publications on the issues under study }\end{array}$ \\
\hline $\begin{array}{l}\text { 2. Calculation of the progressive values of the industrial } \\
\text { structure for different variants of its division into } \\
\text { sectors and assessment of the progressive industrial } \\
\text { structure of the world countries }\end{array}$ & $\begin{array}{l}\text { 2.1. Analyzing the industrial structure of the world countries in accordance with the 3-sector } \\
\text { division and calculating the progressive value in the case of } 3 \text {-sector industrial division } \\
\text { 2.2. Analyzing the industrial structure of the world countries in terms of technological level } \\
\text { and calculating the progressive value when dividing the industry into sectors by } \\
\text { technological level } \\
\text { 2.3. Analyzing the industrial structure of the world countries in terms of types of economic } \\
\text { activity and calculating the progressive value when dividing the industry into sectors by TEA } \\
\text { 2.4. Analyzing the progressiveness of the industrial structure of the world countries by } \\
\text { various sectoral divisions based on the progressive values obtained }\end{array}$ & $\begin{array}{l}\text { Methods: grouping and classification, averaging. } \\
\text { Statistical basis: the data of inter-branch balances for } 36 \text { countries of the world } \\
\text { (WIOD base) }\end{array}$ \\
\hline $\begin{array}{l}\text { 3. Integral assessment of correspondence of the } \\
\text { industrial structure of the world countries with its } \\
\text { progressive state }\end{array}$ & $\begin{array}{l}\text { 3.1. Developing the integral indicator of correspondence of the industrial structure with its } \\
\text { progressive state } \\
\text { 3.2. Calculating the integral indicator of correspondence of the industrial structure with its } \\
\text { progressive state for the studied sample of countries }\end{array}$ & $\begin{array}{l}\text { Methods: method for calculating the integral indicator } \\
\text { Statistical basis: the data of inter-branch balances for } 36 \text { countries of the world } \\
\text { (WIOD base), the results of preliminary calculations (2.1-2.3) }\end{array}$ \\
\hline \multirow[t]{2}{*}{$\begin{array}{l}\text { 4. Justification or refutation of the hypothesis about } \\
\text { influence of the progressiveness of the industrial } \\
\text { structure on sustainable economic development and } \\
\text { quality of life of the population of the world countries }\end{array}$} & $\begin{array}{l}\text { 4.1. Dividing the studied world countries by the GVA per capita (as the summarizing } \\
\text { indicator of economic development) } \\
\text { 4.2. Dividing the studied world countries by the Human Development Index (HDI) (as the } \\
\text { summarizing indicator of quality of life of the population) }\end{array}$ & $\begin{array}{l}\text { Methods: analysis and synthesis, grouping and classification } \\
\text { Statistical basis: the data of inter-branch balances for } 36 \text { countries of the world } \\
\text { (WIOD base) } \\
\text { Methods: analysis and synthesis, grouping and classification } \\
\text { Statistical basis: the data of Human Development Reports on Human Development } \\
\text { Index }\end{array}$ \\
\hline & $\begin{array}{l}\text { 4.3. Analyzing the influence of correspondence of the industrial structure with its } \\
\text { progressive state on the sustainable economic development and quality of life of the } \\
\text { population in the world countries }\end{array}$ & $\begin{array}{l}\text { Methods: cluster analysis } \\
\text { Statistical basis: the results of preliminary calculations }(3.2,4.1 \text { and } 4.2)\end{array}$ \\
\hline
\end{tabular}

Source: developed by the authors. 
The third part of the study involves an integral assessment of the correspondence of the industry structure of the world countries with its progressive state based on the calculated in the previous part values of the progressive structure of the industry of the world countries by various criteria.

In the general case, the integral indicator is a convolution of a set of particular indicators (as such, in our study, the values of the criteria for the progressiveness of the industrial structure across the world countries are used) The application of integral assessment in economic research is usually caused by the need to obtain a comprehensive picture of the state of the process (object) under study. Thus, the use of the integral indicator in this study is due to the need to obtain a comprehensive assessment of the correspondence of the industry structure of the world countries with its progressive state by convoluting the values of the calculated criteria of progressiveness.

Currently, there are many ways to calculate the integral indicator, which differ from each other in factors that are analyzed and the mathematical expression of the indicator. The most used of them are the method for constructing the integral indicator by summarizing individual indicators (linear model), the method for constructing it by summarizing the weighted arithmetic average of individual indicators, the method of geometric aggregation (which implies multiplying the weighted geometric average of individual indicators), the distance method. In this study, based on its objectives and the specifics of the preliminary calculated criteria of progressiveness, it is proposed to use the method of constructing the integral indicator based on the sum of arithmetically weighted indicators.

The fourth part of the study deals with the justification or refutation of the hypothesis about the influence of the industrial structure on the economic development and quality of life of the population in the countries of the world. The main research method used for this purpose is one of the methods of multidimensional classification-cluster analysis.

As is known, cluster analysis is a multidimensional statistical procedure that involves collecting data on a sample of objects with a subsequent division of these objects into relatively homogeneous groups. In the general case, cluster analysis solves the problem of constructing a classification model, i.e., breaking down the input set of objects and features into homogeneous groups (clusters).

Different directions of application of cluster analysis can be reduced to four main tasks: developing a typology or classification; studying conceptual schemes for grouping objects; developing hypotheses based on data research; testing research hypotheses by determining whether groups of objects similar in a number of features can really be singled out in the data analyzed. The focus of the last task is fully consistent with the purpose of our study, according to which we plan to prove or refute the relationship between progressiveness of the industrial structure, economic development and quality of life of the population of the world countries by determining whether the countries under study can be correctly grouped by the analyzed characteristics: 1 -integral indicator of correspondence of the industrial structure with its progressive state; 2-GVA per capita (as the summarizing indicator of economic development of the countries); 3-Human Development Index (HDI) (as the summarizing indicator of quality of life of their population).

The value of the first indicator for the countries of the world is calculated in the third part of the study, the value of the second indicator is formed based on the data of inter-branch balances [7], the value of the third one is obtained using the data of Human Development Reports [44].

It should be noted that in modern studies the indicator of quality of life is considered as the most generalized complex criterion describing a certain final result of socio-economic development. Quality of life is a complex characteristic that includes both the objectively existing degree of and conditions for satisfaction of a wide range of tangible and intangible needs expressed in quantitative and qualitative consumption of material and spiritual goods, as well as the subjective perception of the degree of satisfaction of the whole spectrum of needs, including the need for self-realization and individual freedoms (Kyzym et.al. (2004) [45]). The main indicator officially used by UN experts to assess quality of life of the population is Human Development Index (HDI). It is a composite indicator characterizing human development in countries and regions of the world and is annually calculated by experts of the United Nations Development Program (UNDP) together with the group of 
independent international experts who use, along with analytical developments, statistics of national institutions and international organizations. The indicator is an integral estimate of three components that characterize life expectancy, level of education and income of the world population (Kyzym et.al. (2004) [45]). It has been widely used in scientific research in the field of socio-economic development of countries and territories (Iacobuta et. al. (2019) [46], Jednak et. al. (2018) [47] and other) to assess, analyze and compare the achieved quality of life in 189 countries of the world since 1990, so it is proposed to use it for our study as well.

It is known that the methods of cluster analysis are divided into two groups: hierarchical and non-hierarchical.

The essence of hierarchical clustering is a sequential grouping of small clusters into larger ones (agglomerative methods-Agglomerative Nesting, AGNES) or division of large clusters into smaller ones (divisive methods-Divisive Analysis, DIANA). In this regard, it should be noted that hierarchical clustering is mainly used for small amounts of data.

With a large number of observations, hierarchical methods of cluster analysis are inappropriate. In such cases, non-hierarchical methods, which imply breaking down the input data set into a certain number of individual clusters, are used. There are various algorithms for performing this division. The most common among them is the k-means algorithm, the general idea of which is that objects are broken down into clusters in the way that the means in the clusters (for all variables) differ from each other as much as possible, which corresponds to the objectives of our study.

Thus, taking into consideration the selection of input data, research tasks, and the specifics of the existing cluster analysis algorithms, in our study, we will apply non-hierarchical cluster analysis based on the k-means algorithm, to implement these algorithms, the STATISTICA 7.0 software package will be used.

Therefore, the analysis of the clustering of the world countries, obtained as a result of the study, will allow us to prove or refute the hypothesis about influence of the progressiveness of the industrial structure on economic development and quality of life of the population of the world countries.

\section{Results}

Let's consider the essence of the following concepts: 'structure', 'economic structure' and 'industrial structure'.

The 'structure' concept (from Latin 'structura' — building, location, order, etc.) is considered in the philosophical literature as "a set of stable links of the system which ensure preservation of its properties under different external and internal changes; the base characteristic of the system is its invariant aspect" [48]. The modern economic dictionary interprets the 'structure' concept as a division into parts by certain properties, establishment of mutual links between these components, composition and construction of an economic object [49]. So, the above interpretations speak about integrity, form of construction of the object/system and a nature of interaction of its elements. Such an understanding of the idea of the 'structure' concept is the basis of definition of the 'economic structure' concept.

At the same time, the analysis of the studies in this subject shows that researchers differently interpret the 'economic structure' concept and its study is one of the complex problems in the modern economic theory. One group of economists defines the 'economic structure' concept as the plural of elements of the economy, which is considered together with the links and correlations between them, including formation of different combinations with their generalized links and relations. The other group considers the 'economic structure' concept from the point of view of construction of the production in the technical, cost and organic forms.

Content analysis of interpretations of the 'economic structure' concept in the studies [27,50-52] showed that the majority of researchers focus their attention on the fact that the 'economic structure' concept is a certain construction of the system of national economy which consists of a number of its elements, mutual links and correlations between them. Thus, due to this, it is recommended to understand the 'industrial structure' concept as a combination and correlation between mutually connected types of economic 
activity, which are parts of the industry and reflect national economic proportions and social division of labour, which is inherent in the country.

The scientific literature and practice offer, when analyzing the industrial (economic) structure, to specify its certain structural parts: types of economic activity (TEA), production of capital goods (A group) and production of consumer goods (B group), sectors by the technological level, mining and manufacturing industry and so on.

Based on the indicators of economic security, which are stated in the scientific literature, it is proposed to consider the country's industrial structure by the following classification of sectors for assessing the real sector of economy: by TEA, by the technological level and by the processing depth (3-sector structure) (see Figure 1).

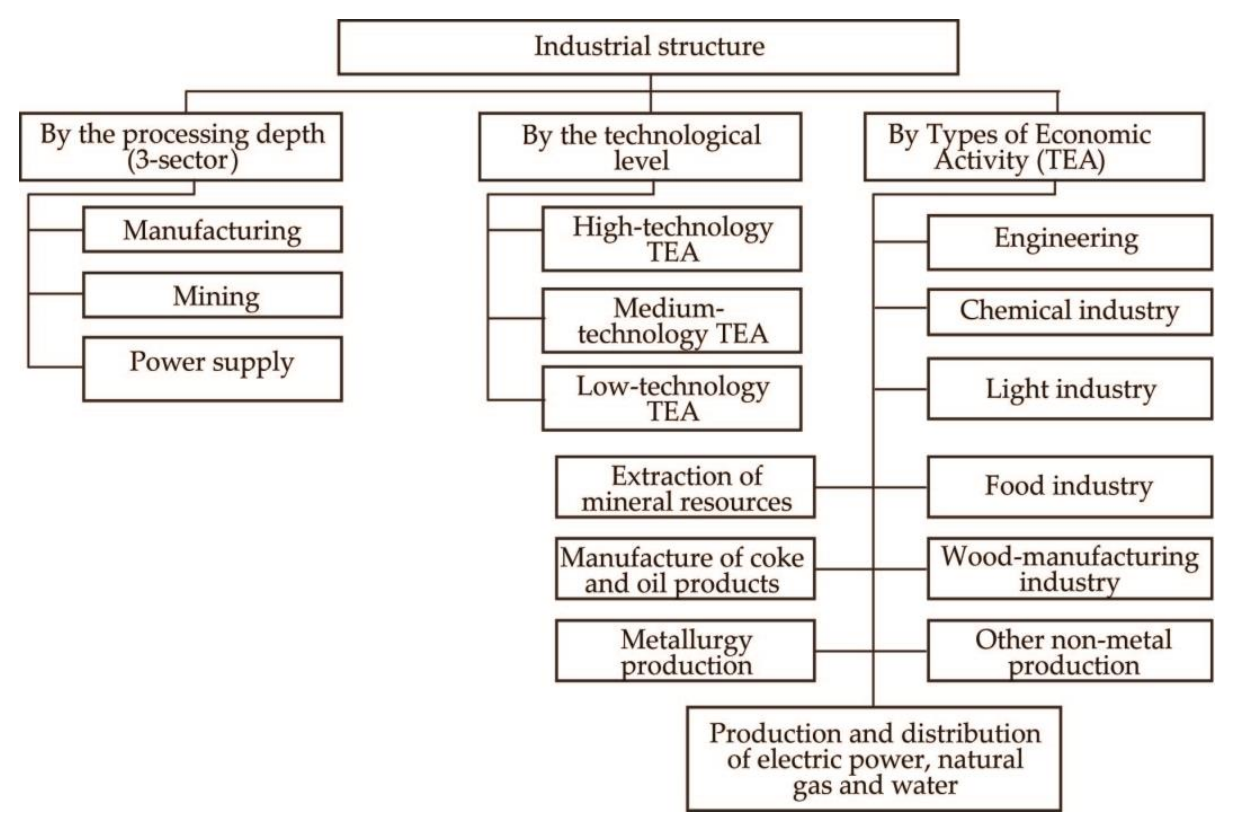

Figure 1. Classification of sectors of the country industry by different features. Source: developed by the authors

There are different definitions in the scientific literature with respect to the industrial structure: 'progressive', 'rational', 'effective' and 'optimal'. The essence of the above concepts is represented in Table 2.

Table 2. Essence of the concepts that characterize the industrial structure.

\begin{tabular}{cc}
\hline Concept & Essence \\
\hline Progressive & Advanced and gradually growing \\
Rational & Reasonably justified and expedient \\
Effective & Efficient \\
Optimal & The most favourable \\
\hline
\end{tabular}

As we can see from Table 2, the above concepts are close in meaning. The current study will use the 'progressive industrial structure' term for characterizing the industrial structure as a term which reflects the goals of industrial development most clearly.

Researchers offer different recommended values of progressiveness of the industrial structure. Thus, for example, Pirog (2011) [54] offered the following requirements to the post-industrial society from the industrial structure point of view: 
1. For the branch structure of the national economy: $20 \%$ have to fall on the processing branches of industry; $25 \%$-financial sphere; $22 \%$-sphere of services; and 33\%-other branches.

2. For the technological structure of the national economy: $20 \%$ have to fall on the high-technology productions; $30 \%$-medium-high-technology productions; 20\%-medium-low-technology productions and 30\%-low-technology productions.

3. For the technological structure of the branches of the manufacturing industry (within $20 \%$ of the national economy structure): $50 \%$ have to fall on the total part of the high-technology and medium-high-technology productions (out of which $20 \%$-high-technology productions and 30\%-medium-high-technology productions) and 50\%-medium-low-technology and low-technology productions [54].

Akayeva and Sokolov (2016) [55] identified the optimal technological structure for economies of the developed countries, in which the manufacturing industry consists of $20 \%$ of high-technology productions, $28 \%$-medium-high-technology productions, $27 \%$-medium-low-technology productions and $25 \%$-low-technology productions.

The above recommended progressive (optimal) industrial structures were obtained by researchers through calculation and generalization of the data by the most efficient developed world countries.

Thus, scientists consider the manufacturing sector and high-tech TEA (which, first of all, refers to engineering) most progressive.

Respective calculations in accordance with the 3-sector industrial division were carried out within this study for identifying the progressive industrial structure (see Figure 1) by 36 world countries and their average values for 3 years (2009, 2011 and 2014).

The conducted calculations showed that the average value of the specific weight of the GVA of the manufacturing industry (SWM) in the countries' industry for 2009-2014 was 76.12\% (Table A2 Appendix B). This value is accepted in the current article as the progressive one for the 3-sector division of the industrial structure.

The diagram of the division of the studied world countries looked as follows in 2014 by the value of the specific weight of GVA of the manufacturing industry in the general volume of the industrial GVA (Figure 2).

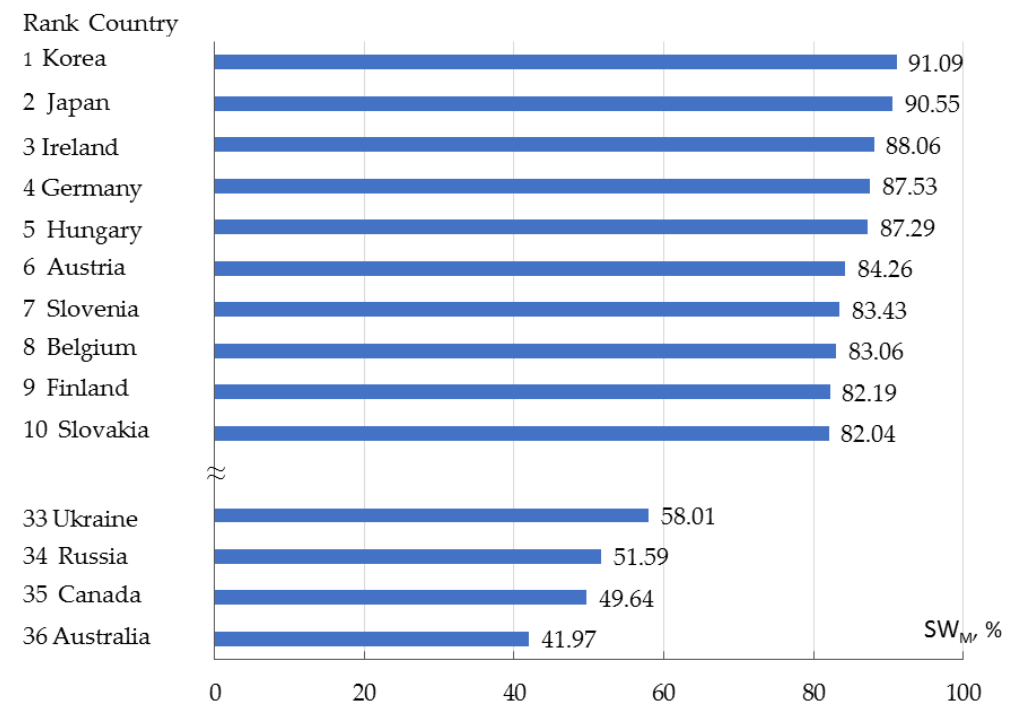

Figure 2. Diagram of the division of the world countries by the specific weight of the manufacturing industry GVA $\left(\mathrm{SW}_{\mathrm{M}}\right)$ in the general volume of the industrial GVA in 2014. Source: developed by the authors on the basis of the data [7].

It can be seen from Figure 2 that the following world countries had the biggest specific weights of the manufacturing industry GVA in the general volume of the industrial GVA in 2014: Korea—91.09\%, 
Japan-90.55\%, Ireland-88.06\%, Germany-87.53\% and Hungary-84.26\%, while the smallest ones: Australia-41.97\%, Canada-49.64\%, Russia- $51.59 \%$ and Ukraine- $58.01 \%$.

The conducted calculations with respect to the industrial structure of the studied world countries for the period of 2009-2014 by the technological level of production (see Figure 1) allowed to identify the industrial structure of the studied countries by the technological level (Table 3). The industries were classified into relevant sectors by technological level in accordance with [56].

Table 3. The industrial structure of the world countries by the technology level.

\begin{tabular}{|c|c|c|c|c|c|c|c|c|c|c|c|c|c|c|c|c|c|c|c|}
\hline \multirow{3}{*}{ No. } & \multirow{3}{*}{ Country } & \multicolumn{6}{|c|}{ High-Technology Sector (HTS) } & \multicolumn{6}{|c|}{ Medium-Technology Sector (MTS) } & \multicolumn{6}{|c|}{ Low-Technology Sector (LTS) } \\
\hline & & \multicolumn{2}{|c|}{2009} & \multicolumn{2}{|c|}{2011} & \multicolumn{2}{|c|}{2014} & \multicolumn{2}{|c|}{2009} & \multicolumn{2}{|c|}{2011} & \multicolumn{2}{|c|}{2014} & \multicolumn{2}{|c|}{2009} & \multicolumn{2}{|c|}{2011} & \multicolumn{2}{|c|}{2014} \\
\hline & & $1^{*}$ & $2^{* *}$ & 1 & 2 & 1 & 2 & 1 & 2 & 1 & 2 & 1 & 2 & 1 & 2 & 1 & 2 & 1 & 2 \\
\hline 1 & Australia & 11.43 & 36 & 9.76 & 36 & 13.41 & 35 & 21.95 & 32 & 19.41 & 33 & 23.53 & 28 & 66.62 & 1 & 70.83 & 1 & 63.06 & 1 \\
\hline 2 & Austria & 39.09 & 10 & 40.16 & 7 & 43.90 & 10 & 30.43 & 14 & 31.43 & 14 & 29.09 & 16 & 30.48 & 28 & 28.41 & 28 & 27.01 & 28 \\
\hline 3 & Belgium & 36.60 & 13 & 37.52 & 13 & 44.30 & 9 & 31.88 & 12 & 35.12 & 3 & 29.09 & 17 & 31.52 & 26 & 27.35 & 31 & 26.62 & 29 \\
\hline 4 & Bulgaria & 17.82 & 31 & 17.82 & 32 & 22.51 & 28 & 34.55 & 4 & 34.55 & 7 & 30.37 & 12 & 47.63 & 11 & 47.63 & 11 & 47.13 & 10 \\
\hline 5 & Brazil & 27.87 & 21 & 26.42 & 23 & 30.42 & 21 & 32.83 & 9 & 3112 & 15 & 16.66 & 34 & 39.30 & 20 & 42.46 & 18 & 52.93 & 5 \\
\hline 6 & United Kingdom & 31.26 & 17 & 31.63 & 17 & 35.41 & 18 & 24.76 & 26 & 25.72 & 26 & 27.42 & 20 & 43.98 & 15 & 42.65 & 17 & 37.17 & 20 \\
\hline 7 & Greece & 12.74 & 35 & 12.74 & 35 & 12.70 & 36 & 36.54 & 2 & 36.54 & 2 & 45.90 & 1 & 50.71 & 7 & 50.71 & 7 & 41.40 & 18 \\
\hline 8 & Denmark & 38.13 & 11 & 33.53 & 16 & 46.35 & 7 & 18.40 & 34 & 18.42 & 34 & 18.38 & 33 & 43.47 & 17 & 48.05 & 10 & 35.27 & 22 \\
\hline 9 & Estonia & 21.46 & 28 & 21.46 & 30 & 22.38 & 29 & 32.53 & 11 & 32.53 & 12 & 34.02 & 3 & 46.01 & 13 & 46.01 & 14 & 43.60 & 13 \\
\hline 10 & India & 29.85 & 20 & 29.84 & 21 & 30.09 & 22 & 29.00 & 20 & 29.28 & 19 & 27.05 & 21 & 41.15 & 18 & 40.88 & 20 & 42.86 & 16 \\
\hline 11 & Ireland & 57.47 & 1 & 56.69 & 2 & 42.27 & 12 & 9.68 & 36 & 8.77 & 36 & 13.11 & 36 & 32.84 & 24 & 34.54 & 22 & 44.62 & 12 \\
\hline 12 & Spain & 30.01 & 19 & 29.99 & 20 & 33.30 & 20 & 33.58 & 7 & 34.57 & 6 & 32.58 & 6 & 36.42 & 21 & 35.44 & 21 & 34.12 & 23 \\
\hline 13 & Italy & 34.90 & 16 & 35.34 & 15 & 38.43 & 15 & 29.18 & 19 & 31.03 & 16 & 29.71 & 13 & 35.92 & 22 & 33.63 & 25 & 31.85 & 25 \\
\hline 14 & Canada & 19.56 & 30 & 27.02 & 22 & 20.20 & 31 & 20.52 & 33 & 21.75 & 30 & 24.70 & 24 & 59.91 & 3 & 51.23 & 6 & 55.10 & 3 \\
\hline 15 & China & 35.37 & 15 & 35.37 & 14 & 37.08 & 17 & 23.52 & 29 & 23.52 & 28 & 19.76 & 32 & 41.11 & 19 & 41.11 & 19 & 43.16 & 14 \\
\hline 16 & Korea & 57.14 & 2 & 58.18 & 1 & 60.71 & 1 & 24.43 & 28 & 25.81 & 25 & 24.27 & 25 & 18.43 & 36 & 16.01 & 36 & 15.02 & 36 \\
\hline 17 & Latvia & 14.71 & 33 & 14.71 & 33 & 16.84 & 32 & 34.92 & 3 & 34.92 & 4 & 32.76 & 5 & 50.37 & 9 & 50.37 & 9 & 50.40 & 8 \\
\hline 18 & Lithuania & 21.63 & 26 & 21.63 & 28 & 24.82 & 26 & 32.66 & 10 & 32.66 & 11 & 26.50 & 23 & 45.71 & 14 & 45.71 & 15 & 48.68 & 9 \\
\hline 19 & Mexico & 21.60 & 27 & 21.67 & 27 & 28.10 & 24 & 15.28 & 35 & 14.85 & 35 & 16.38 & 35 & 63.12 & 2 & 63.47 & 2 & 55.52 & 2 \\
\hline 20 & Nether-lands & 25.60 & 24 & 31.05 & 18 & 34.89 & 19 & 24.67 & 27 & 21.75 & 31 & 22.11 & 30 & 49.73 & 10 & 47.20 & 13 & 43.00 & 15 \\
\hline 21 & Germany & 53.47 & 3 & 55.83 & 3 & 58.77 & 2 & 27.66 & 22 & 27.33 & 21 & 24.05 & 26 & 18.88 & 35 & 16.84 & 35 & 17.18 & 35 \\
\hline 22 & Poland & 26.33 & 22 & 21.84 & 26 & 29.01 & 23 & 29.75 & 17 & 34.58 & 5 & 32.77 & 4 & 43.92 & 16 & 43.58 & 16 & 38.22 & 19 \\
\hline 23 & Portugal & 22.83 & 25 & 22.83 & 25 & 21.93 & 30 & 29.78 & 16 & 29.78 & 18 & 31.03 & 11 & 47.40 & 12 & 47.40 & 12 & 47.04 & 11 \\
\hline 24 & Russia & 14.70 & 34 & 14.68 & 34 & 15.22 & 34 & 33.46 & 8 & 32.79 & 10 & 32.03 & 7 & 51.83 & 6 & 52.53 & 5 & 52.75 & 6 \\
\hline 25 & Romania & 26.27 & 23 & 26.27 & 24 & 25.91 & 25 & 23.14 & 30 & 23.14 & 29 & 31.59 & 8 & 50.59 & 8 & 50.59 & 8 & 42.50 & 17 \\
\hline 26 & Slovakia & 30.27 & 18 & 30.27 & 19 & 41.87 & 13 & 41.06 & 1 & 41.06 & 1 & 34.46 & 2 & 28.67 & 30 & 28.67 & 27 & 23.67 & 31 \\
\hline 27 & Slovenia & 41.24 & 6 & 41.24 & 6 & 46.51 & 6 & 30.85 & 13 & 30.85 & 17 & 31.50 & 10 & 27.92 & 31 & 27.92 & 30 & 21.98 & 32 \\
\hline 28 & USA & 37.82 & 12 & 38.66 & 11 & 39.39 & 14 & 27.18 & 24 & 26.89 & 23 & 23.48 & 29 & 34.99 & 23 & 34.46 & 23 & 37.12 & 21 \\
\hline 29 & Turkey & 20.95 & 29 & 21.46 & 29 & 23.75 & 27 & 22.72 & 31 & 21.46 & 32 & 21.26 & 31 & 56.33 & 4 & 57.08 & 3 & 54.99 & 4 \\
\hline 30 & Hungary & 48.54 & 4 & 54.90 & 4 & 56.05 & 3 & 28.49 & 21 & 26.94 & 22 & 23.94 & 27 & 22.97 & 34 & 18.16 & 34 & 20.01 & 34 \\
\hline 31 & Ukraine & 17.14 & 32 & 21.07 & 31 & 16.40 & 33 & 27.53 & 23 & 24.28 & 27 & 31.56 & 9 & 55.34 & 5 & 54.64 & 4 & 52.05 & 7 \\
\hline 32 & Finland & 40.73 & 7 & 39.50 & 10 & 42.60 & 11 & 26.75 & 25 & 26.60 & 24 & 27.59 & 19 & 32.52 & 25 & 33.90 & 24 & 29.80 & 26 \\
\hline 33 & France & 39.28 & 9 & 37.72 & 12 & 37.53 & 16 & 29.69 & 18 & 33.51 & 8 & 29.32 & 14 & 31.03 & 27 & 28.78 & 26 & 33.15 & 24 \\
\hline 34 & Czech Republic & 35.75 & 14 & 40.13 & 8 & 48.93 & 4 & 33.93 & 5 & 31.78 & 13 & 29.21 & 15 & 30.32 & 29 & 28.09 & 29 & 21.86 & 33 \\
\hline 35 & Sweden & 42.50 & 5 & 44.06 & 5 & 48.63 & 5 & 30.23 & 15 & 29.10 & 20 & 27.62 & 18 & 27.27 & 32 & 26.84 & 33 & 23.75 & 30 \\
\hline 36 & Japan & 39.48 & 8 & 39.55 & 9 & 45.61 & 8 & 33.61 & 6 & 33.50 & 9 & 27.05 & 22 & 26.91 & 33 & 26.95 & 32 & 27.34 & 27 \\
\hline \multirow{2}{*}{\multicolumn{2}{|c|}{ Average value }} & 31.55 & & 32.04 & & 34.85 & & 28.28 & & 28.37 & & 27.15 & & 40.17 & & 39.58 & & 38.00 & \\
\hline & & \multicolumn{6}{|c|}{32.82} & \multicolumn{6}{|c|}{27.93} & \multicolumn{6}{|c|}{39.25} \\
\hline
\end{tabular}

It is seen from Table 3 that the average values of the industrial structure by 36 world countries for the period of 2009-2014 are: high-technology sector-32.82\%, medium-technology sector- $27.93 \%$ and low-technology sector- $39.25 \%$. This value for the high-technology sector is considered in this study as the progressive value for technological division of the industry into sectors. The diagram of division of Ukraine and world countries looks as follows by the specific weight indicator of the GVA high-technology sector $\left(\mathrm{SW}_{\mathrm{HTS}}\right)$ in the industrial GVA (Figure 3).

It can be seen from Figure 3 that the following world countries had the largest specific weights of the GVA high-technology sector in the general volume of the industrial GVA in 2014: Korea-60.71\%, Germany-58.77\%, Hungary-56.05\%, Czech Republic-48.93\% and Sweden-48.63\%, while the smallest ones: Greece-12.7\%, Australia-14.7\%, Russia-15.22\% and Ukraine-16.4\%.

Calculations, which have been carried out with respect to the industrial structure of the studied world countries for the period of 2009-2014 by types of economic activity (TEA) (see Figure 1), showed that the average value of the industrial structure by them for the period of 2009-2014 by Engineering TEA (one of the most high-technological industry) was 22.81\% (see Table A3 Appendix C). This value is considered to be progressive in this study for the division of the industry by TEA sectors. 


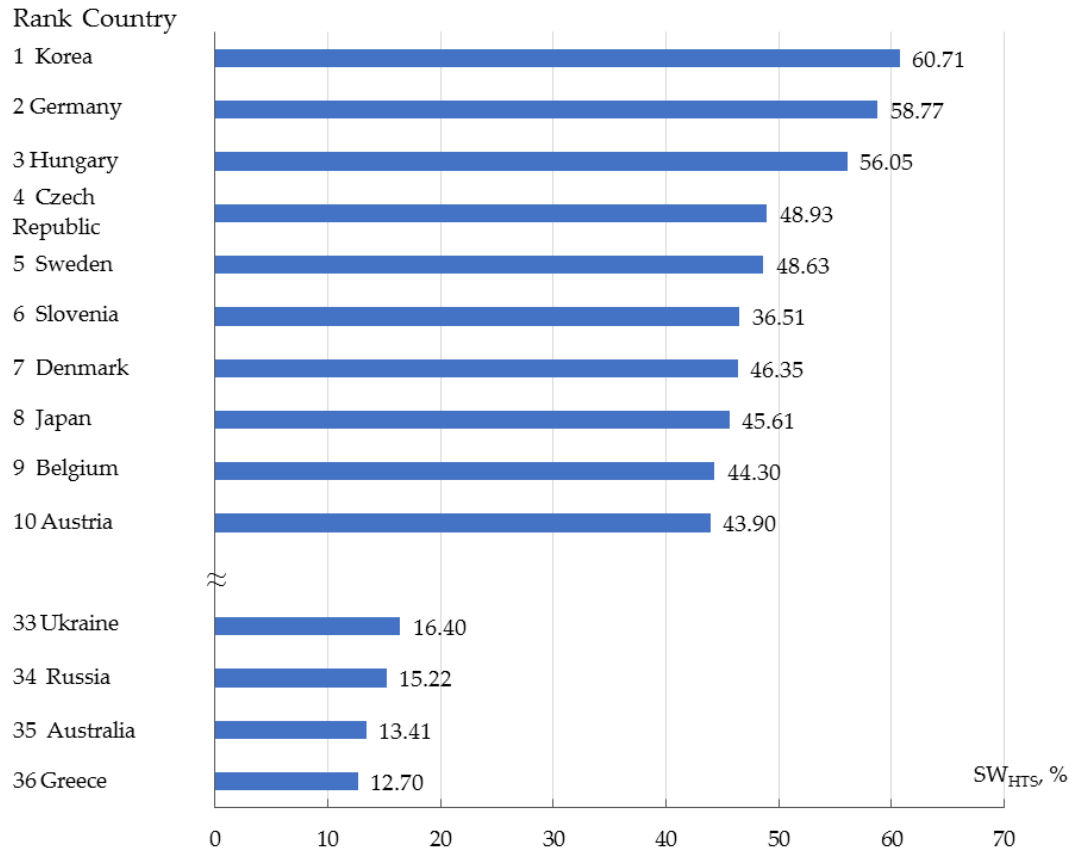

Figure 3. Diagram of the division of the studied world countries by the specific weight of the GVA high-technology sector ( $\mathrm{SW}_{\mathrm{HTS}}$ ) in the general industrial GVA volume in 2014. Source: developed by the authors on the basis of the data [7].

The diagram of the division of Ukraine and world countries by the indicator of the specific weight of the Engineering TEA in the industrial GVA is shown in Figure 4.

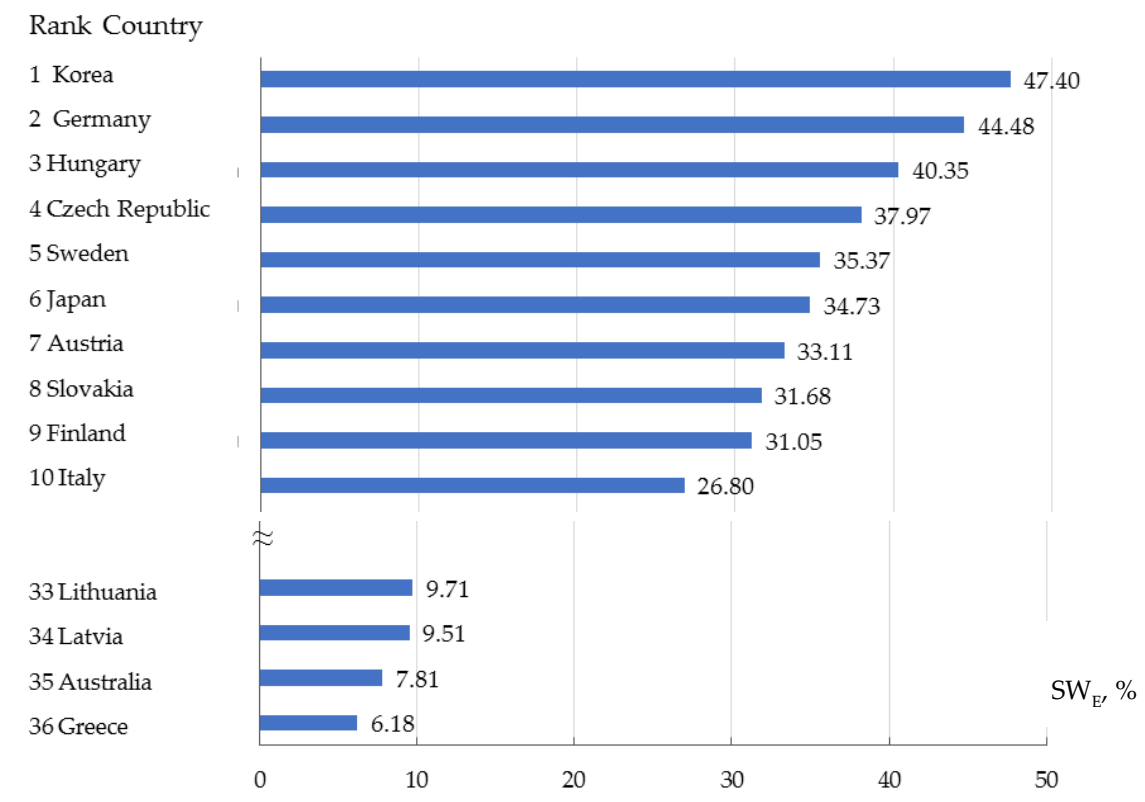

Figure 4. Diagram of division of the studied world countries by the specific weight of the Engineering TEA GVA $\left(\mathrm{SW}_{\mathrm{E}}\right)$ in the general volume of the industrial GVA in 2014. Source: developed by the authors on the basis of the data [6].

It is seen from Figure 4 that the following countries had the largest specific weight of the Engineering TEA in the general volume of the industrial GVA in 2014: Korea-47.40\%, Germany-44.48\%, Hungary-40.35\%, Czech Republic-37.97\% and Sweden-35.37\%, while the smallest one: Greece-6.18\%, Australia-7.81\% and Latvia-9.51\%. 
Table A4 Appendix D contains indicators of progressiveness of the world countries industrial structure by various sectoral divisions in 2014. Table A4 shows that the world countries have different levels of achievements by the given indicators. Thus, on the basis of their analysis it is impossible to get an unambiguous conclusion about the correspondence of the structure of their industry with its progressive state. In this case, it is necessary to carry out an integral assessment, which will allow to obtain the composite indicator of progressiveness of the industrial structure of the world countries.

In this regard, for the integral assessment of the correspondence of the industrial structure of the world countries with its progressive state, it is proposed to use the following integral indicator:

$$
\mathrm{I}_{\mathrm{PS}}=\alpha_{1} \frac{\mathrm{K}_{1 \mathrm{i}}}{\mathrm{K}_{1 \pi}}+\alpha_{2} \frac{\mathrm{K}_{2 \mathrm{i}}}{\mathrm{K}_{2 \pi}}+\alpha_{3} \frac{\mathrm{K}_{3 \mathrm{i}}}{\mathrm{K}_{3 \pi}}
$$

where $\mathrm{I}_{\mathrm{PSi}}$-integral indicator of correspondence of the industrial structure with the industrial structure of the $i$ world country with its progressive state;

$\mathrm{K}_{1 \mathrm{i}}$ and $\mathrm{K}_{1 \pi}$-indicators of the specific weight of the manufacturing industry GVA in the general volume of the industrial GVA of the $i$ world country and its progressive value respectively;

$\mathrm{K}_{2 \mathrm{i}}$ and $\mathrm{K}_{2 \pi}$-indicators of the specific weight of the GVA high-technology sector in the general industrial GVA volume of the $i$ world country and its progressive level respectively;

$\mathrm{K}_{3 \mathrm{i}}$ and $\mathrm{K}_{3 \pi}$-indicator of the Engineering GVA in the general industrial GVA of the $i$ world country and its progressive level respectively;

$\alpha_{1}, \alpha_{2}, \alpha_{3}$-significance of partial indicators of the integral assessment of correspondence of the industrial structure of the world countries with its progressive state.

It is recommended to use average values of the actual level of indicators of assessment of the industrial structure $\left(\mathrm{K}_{1 \pi}, \mathrm{K}_{2 \pi}\right.$ та $\left.\mathrm{K}_{3 \pi}\right)$ as their progressive values by 36 studied world countries, which were calculated above.

Significance of partial indicators of the integral assessment of correspondence of the industrial structure of the world countries with their progressive state $\left(\alpha_{1}, \alpha_{2}, \alpha_{3}\right)$ is identified on the basis of their aggregation (more aggregated are of less significance) in accordance with the 'golden section' scale [57] and equals, respectively: $\alpha_{1}=0.15, \alpha_{2}=0.35, \alpha_{3}=0.5$.

Calculations of the integral indicator of correspondence of the industrial structure of the world countries with its progressive state (see Table A5 Appendix E) allowed to form their following division (Figure 5).

As we can see from Figure 5, a number of countries have such an industrial structure which is better than its progressive state and these countries are: Korea-1.7175, Germany-1.6249, Hungary-1.5153, Czech Republic-1.4332, while the worst ones are in: Australia-0.4987, Russia-0.6246, Ukraine- 0.6705 and Canada-0.6720.

In accordance with the goal of this study let's prove or refute the hypothesis about the influence of the industrial structure on the GVA value per capita and quality of life of the population in the world countries.

To do it we will use the cluster analysis and data with respect to the volumes of the industrial GVA per capita and the Human Development Index (HDI) which is formed by the UN [44].

The diagram of the division of the studied world countries by the GVA per capita indicator looks as follows (Figure 6).

In can be seen from Figure 6 that the largest values of the GVA per capita indicator in 2014 belonged to the following world countries: Denmark-USD 62,549.0 per capita, Australia-USD 62,403.1 per capita, Sweden-USD 59,241.6 per capita, Ireland-55,628.2 per capita and the US-USD 55,033.0 per capita, while the smallest ones: India-USD 1,576.0 per capita, Ukraine-3,104.7 per capita, China-USD 7,683.5 per capita and Bulgaria-USD 7,864.8 per capita.

The diagram of the division of the studied world countries by the Human Development Index (HDI), which is formed by the UN, looks as follows (Figure 7). 


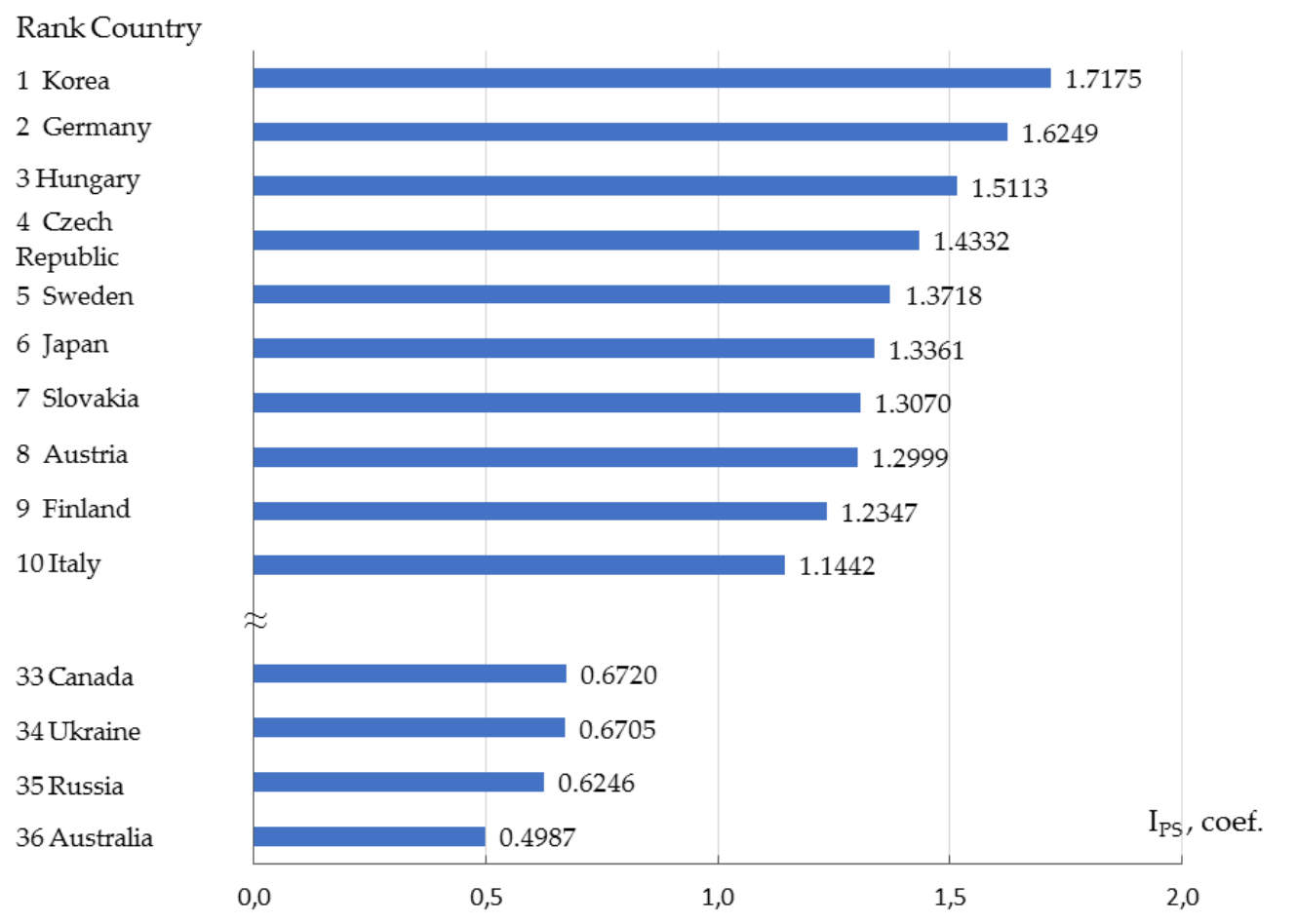

Figure 5. Diagram of division of the world countries by the integral indicator of correspondence of the industrial structure (IPS) with its progressive state in 2014. Source: developed by the authors on the basis of own calculations.

Rank Country

1 Denmark

2 Australia

3 Sweden

4 Ireland

5 USA

6 Netherlands

7 Austria

8 Canada

9 Finland

10 Germany

33 Bulgaria

34 China

35 Ukraine

36 India

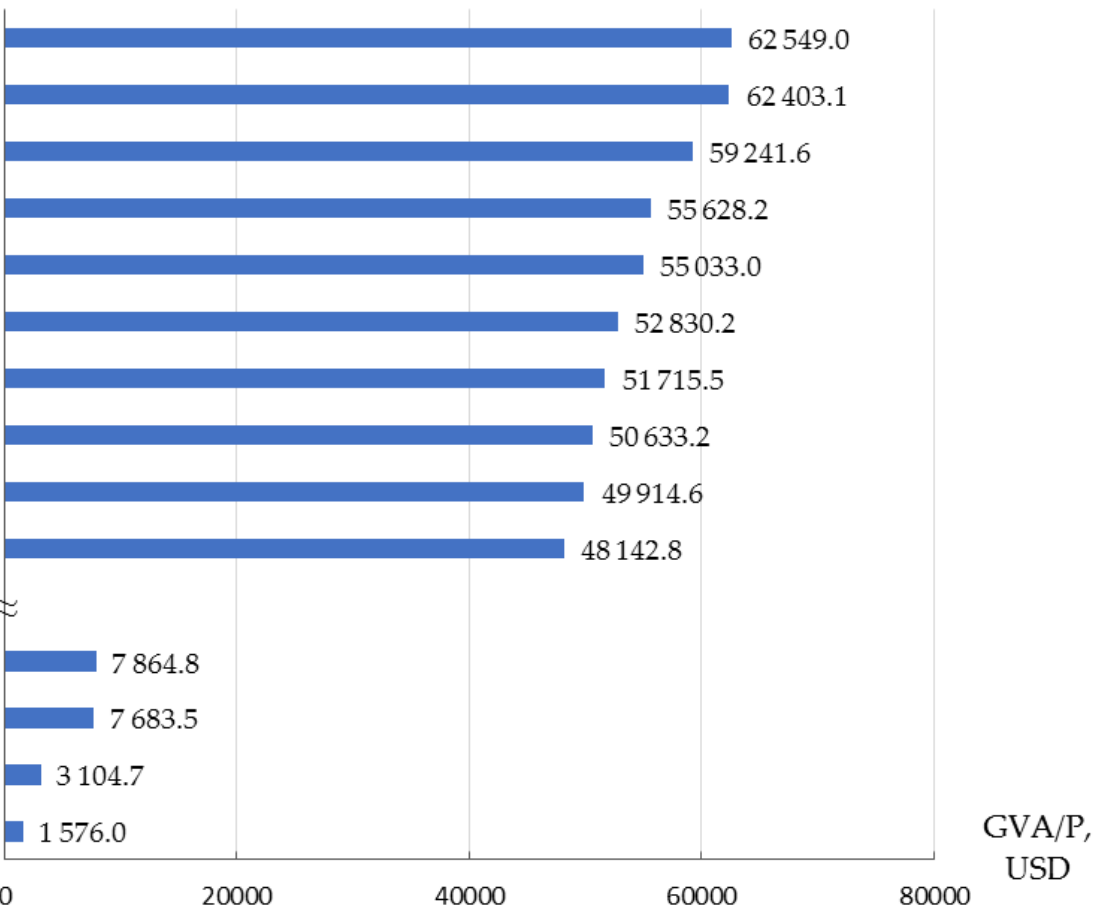

Figure 6. The diagram of the division of the world countries by GVA per capita (GVA/p) in 2014. Source: developed by the authors on the basis of the data [7]. 


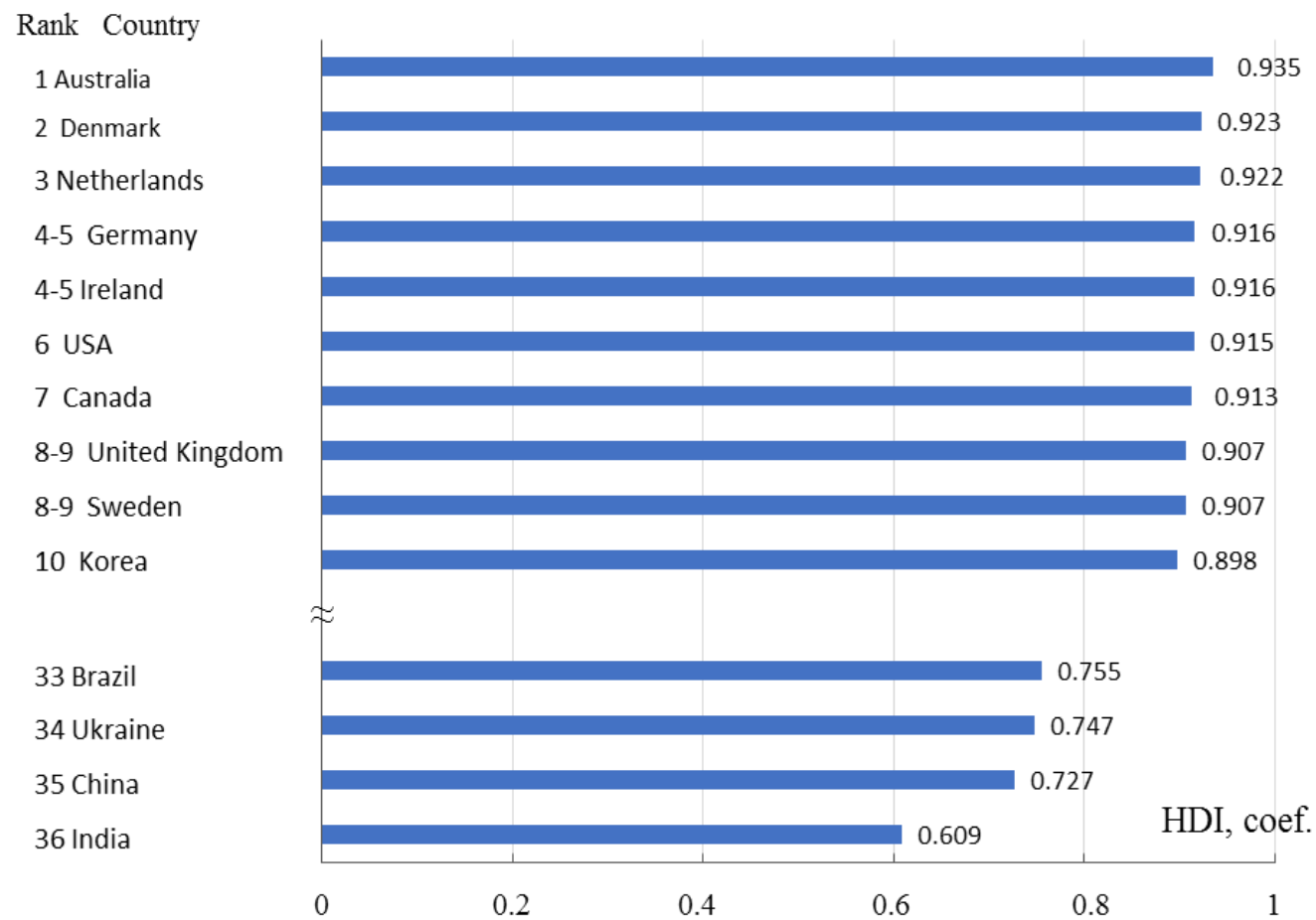

Figure 7. The diagram of the division of the world countries by HDI in 2014. Source: developed by the authors on the basis of the data [44]

It can be seen from Figure 7 that the largest HDI levels belonged to the following countries: Australia—0.935, Denmark-0.923, Netherlands—0.922, Germany-0.916 and Ireland -0.916 , while the smallest ones: India-0.609, China-0.727, Ukraine -0.747 and Brazil-0.755.

Let's study influence of the integral indicator of correspondence of the industrial structure with its progressive state on the indicators of the industrial GVA volume per capita and quality of life of the population with the help of the cluster analysis.

Figure 8 shows the graph of average values of the integral indicator of correspondence of the industrial structure with its progressive state, industrial GVA volume per capita and quality of life of the population by the clusters of the world countries in 2014.

So, the calculations allocated two clusters of the world countries by the integral indicator of correspondence of the industrial structure, quality of life of the population and GVA volume per capita in 2014 (see Table 4).

Table 5 shows indicators that characterize the world countries which belong to the first cluster.

Table 5 shows that the first cluster mainly includes those world countries which have a low GVA volume per capita, low quality of life of the population and such an industrial structure, which is worse than its progressive value both by the integral indicator and various approaches to its structurization.

Table 6 shows indicators that characterize the world countries which belong to the second cluster.

Table 4. Division of the world countries by clusters depending on the integral indicator of correspondence of the industrial structure, indicators of the life quality of the population and industrial GVA volume per capita in 2014.

\begin{tabular}{cc}
\hline 1st Cluster & 2nd Cluster \\
\hline Bulgaria; Brazil; Estonia; India; China; Latvia; & Australia; Austria; Belgium; United Kingdom; Denmark; \\
Lithuania; Mexico; Poland; Portugal; Russia; & Ireland; Spain; Italy; Canada; Korea; Netherlands; \\
Romania; Turkey; Ukraine; Greece & Germany; Slovakia; Slovenia; USA; Hungary; Finland; \\
& France; Czech Republic; Sweden; Japan \\
\hline
\end{tabular}

Source: developed by the authors on the basis of own calculations. 


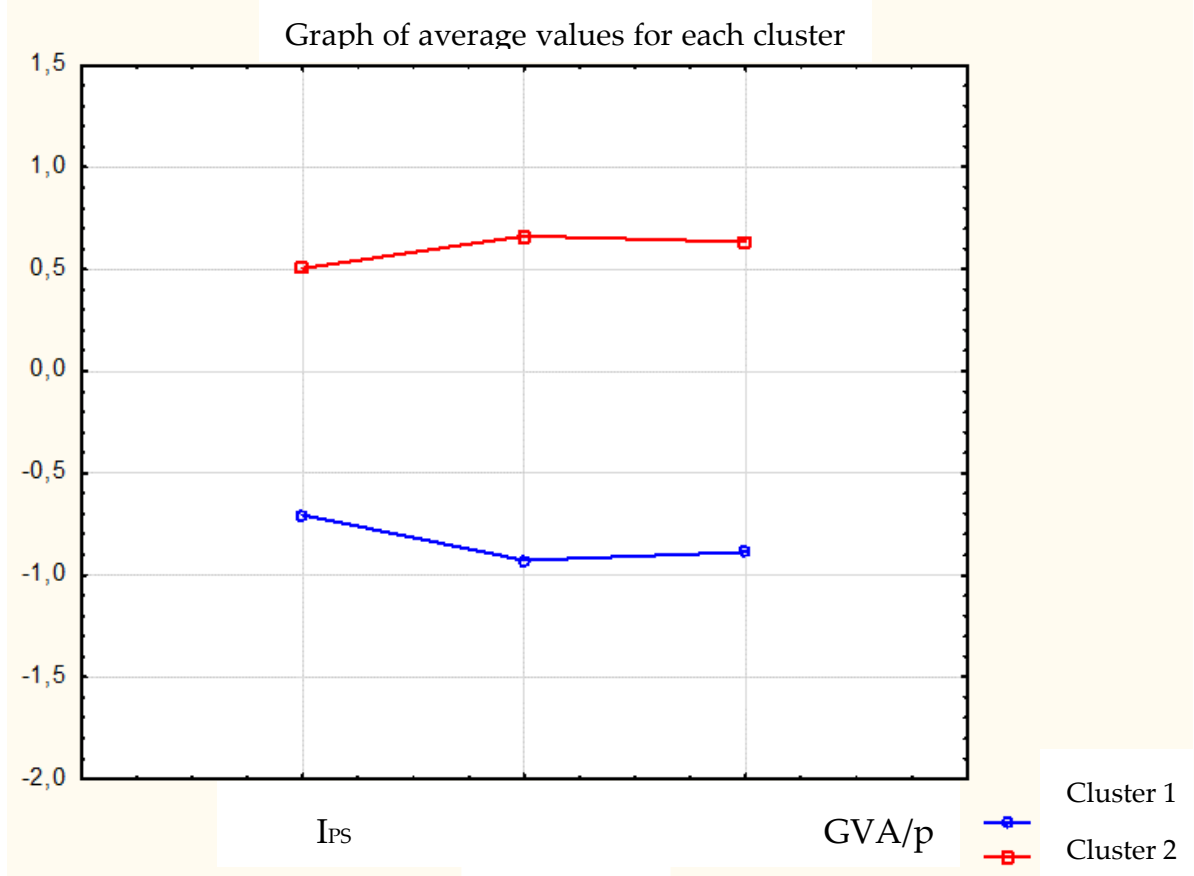

Figure 8. The graph of average values of the integral indicator of correspondence of the industrial structure with its progressive state $\left(\mathrm{I}_{\mathrm{PS}}\right)$, quality of life of the population (HDI), industrial GVA volume per capita (GVA/p) by the clusters of the world countries in 2014. Source: developed by the authors on the basis of own calculations.

Table 6 shows that the second cluster mainly includes the world countries which have a high GVA volume per capita, high quality of life and the industrial structure that is better than its progressive value both by the integral indicator and by various approaches to its structurization.

Thus, the above clusterization and analysis confirmed the hypothesis according to which the approach of the industrial structure of the world countries to its progressive state positively influences the country's economic development and quality of life of its population.

Table 5. Indicators that characterize the world countries which belong to the first cluster.

\begin{tabular}{|c|c|c|c|c|c|c|c|c|c|c|c|c|c|}
\hline \multirow{2}{*}{ No. } & \multirow{2}{*}{ Country } & \multicolumn{2}{|c|}{ HDI } & \multicolumn{2}{|c|}{ GVA/p } & \multicolumn{2}{|c|}{$\mathbf{I}_{\mathbf{P S}}$} & \multicolumn{2}{|c|}{$\mathrm{SW}_{\mathbf{M}}$} & \multicolumn{2}{|c|}{ SW $_{\text {HTS }}$} & \multicolumn{2}{|c|}{$\mathrm{SW}_{\mathrm{E}}$} \\
\hline & & $1^{*}$ & $2^{* *}$ & 1 & 2 & 1 & 2 & 1 & 2 & 1 & 2 & 1 & 2 \\
\hline 1 & Bulgaria & 0.782 & 30 & $7,864.8$ & 33 & 0.7541 & 28 & 65.47 & 31 & 22.51 & 28 & 13.09 & 28 \\
\hline 3 & Estonia & 0.861 & 21 & $20,247.2$ & 21 & 0.8482 & 23 & 71.06 & 28 & 22.38 & 29 & 16.75 & 25 \\
\hline 4 & India & 0.609 & 36 & $1,576.0$ & 36 & 0.8869 & 22 & 78.20 & 18 & 30.09 & 22 & 17.30 & 23 \\
\hline 5 & China & 0.727 & 35 & $7,683.5$ & 34 & 1.0358 & 15 & 78.82 & 17 & 37.08 & 17 & 26.45 & 11 \\
\hline 8 & Mexico & 0.756 & 32 & $10,582.4$ & 31 & 0.7980 & 25 & 65.05 & 32 & 28.10 & 24 & 19.56 & 19 \\
\hline 9 & Poland & 0.843 & 23 & $14,345.2$ & 26 & 0.9193 & 19 & 73.82 & 23 & 29.01 & 23 & 17.63 & 22 \\
\hline 10 & Portugal & 0.830 & 25 & $22,077.5$ & 19 & 0.7675 & 27 & 76.67 & 21 & 21.93 & 30 & 12.54 & 29 \\
\hline 11 & Russia & 0.798 & 28 & $14,125.9$ & 28 & 0.6246 & 35 & 51.59 & 34 & 15.22 & 34 & 9.81 & 32 \\
\hline 12 & Romania & 0.793 & 29 & $10,027.0$ & 32 & 0.9181 & 20 & 77.72 & 19 & 25.91 & 25 & 19.58 & 18 \\
\hline 13 & Turkey & 0.761 & 31 & $12,127.5$ & 29 & 0.7441 & 29 & 80.43 & 15 & 23.75 & 27 & 14.21 & 26 \\
\hline
\end{tabular}

*-indicator value; ** - country rank by the indicator value. Source: developed by the authors on the basis of own calculations using the data $[7,44]$. 
Table 6. Indicators that characterize the world countries which belong to the second cluster.

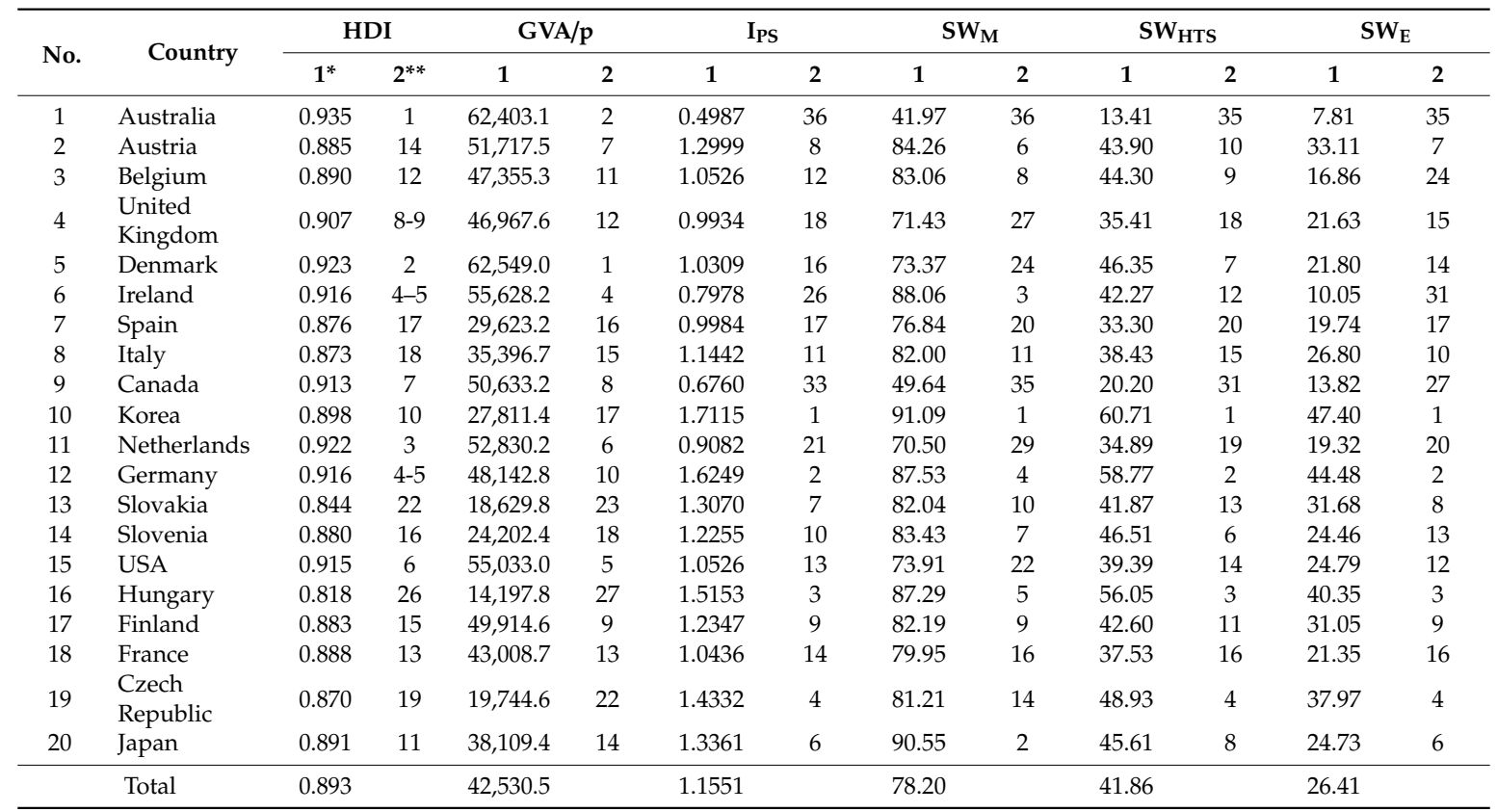

*-indicator value; ** - country rank by the indicator value. Source: developed by the authors on the basis of own calculations using the data $[7,44]$.

\section{Conclusions and Discussion}

Thus, the study allowed us to formulate the following main conclusions:

1. Sustainable development is and will be a key issue to be addressed by the present and future generations. It is obvious that sustainability issues will greatly influence all aspects of human life in economic, social, environmental and political terms in the coming decades. At the same time, production processes in all countries of the world will also be greatly affected by sustainability problems. This is due to the fact that the modern sustainable development paradigm involves the elaboration of new solutions to ensure sustainable development of the manufacturing sector, creation and adoption of technological innovations, and application of new business process models.

2. Currently, scientists continue discussions about which sector plays the leading role in sustainable economic growth of countries of the world, the service sector or industrial one. In our opinion, there are more valid arguments in favor of the fact that despite the significant growth in the service sector in recent years industry remains the main engine of growth, accumulates achievements of scientific and technological progress and is the driver of innovative development of the national economy

3. As the analysis of statistical data shows, the development of the industry in countries of the world is characterized by various trends, which are reflected in changes in its structure and determine the socio-economic situation of countries as a whole. The processes of structural transformations of the economies (and industrial systems) of countries, which are going on in the world, are accompanied by an increase in the unevenness of their development and determined by the influence of tendencies and technologies of the new industrial revolution. Under these conditions, the governments of countries of the world are forced to search for modern effective directions of structural and industrial policy that, on the one hand, would ensure sustainable economic growth of the country and the corresponding quality of life of its population, and, on the other hand, would use the potential of digital technologies to promote economic diversification, positive structural transformations and increase in the value added.

According to the note by the UNCTAD secretariat [6], the rapid spread of digital technologies across the world results in a shift of the traditional boundaries between individual industries, between industry and the service sector, changes the nature of production processes and business models, having a serious impact on economic diversification and structural transformation in different countries. 
All this poses serious challenges to the economic development of countries. The document [6] also emphasizes that success will depend on the policies to be pursued. Thus, at present, it is important to make a reasonable choice of priorities and directions of the structural and industrial policies of countries, which should be based on a clear idea of the key industrial sectors and types of activities to support in them, taking into account the whole range of development conditions that have developed in the countries and resources available.

4. The choice of the structural and industrial policy of the country should be based on the understanding of what structure of the country's industry is progressive under the current economic conditions, i.e., can lead to progress and sustainable socio-economic growth. This justifies the relevance of studies aimed at pursuing answers to the questions of whether the progressive structure of the country's industry generally influences its economic development and quality of life of its population, and what the general characteristics of the progressive industrial structure are.

5. An attempt to resolve these issues was carried out in the presented research. The results obtained made it possible to confirm the hypothesis about a positive influence of the approach of the industrial structure of the world countries to the progressive state on the sustainable economic development and quality of life of their population. To assess the progressiveness of the structure, it is proposed to use a number of criteria reflecting the share of the manufacturing industry, high-tech TEA, and engineering that are characteristic for the progressive state.

The obtained as a result of the study division of the countries of the world by the indicators of progressiveness of the industrial structure, GVA per capita (as an indicator of the level of economic development), Human Development Index (as an indicator of quality of life of the population) allowed to determine that countries with a progressive structure of industry have a higher quality of life of their population and a higher level of their economic development.

Thus, despite the fact that modern studies suggest that the service sector is an important growth driver for advanced countries, while the manufacturing sector is that for emerging ones, in our opinion, a developed manufacturing sector is an important component of economic growth for the both groups of countries (as confirmed by the results of this study).We believe that the country's ability to develop the service sector depends on the structure and technological level of its industrial sector. Moreover, at present, there is a whole range of high-tech services that are co-products of the manufacturing industry since the industrial sector itself is a key source for generating and adopting new knowledge and technologies. Thus, in our opinion, the growth of the service sector is closely connected with the development of the country's manufacturing industry since the weakening of the production base ultimately leads to a decrease in the quality of services. Furthermore, a developed manufacturing sector has a corresponding effect on the social situation in countries since, firstly, a decrease in the significance of manufacturing in the economies "may lock economies into lower productivity activities and provide well-paid employment only for a select few" [6]; and, secondly, the development of the manufacturing sector, ensuring productivity growth, expands employment and income opportunities, provides a higher level of employment and reduces unemployment in the country. It is clear that for countries with developing economies the problem of ensuring sustainable economic growth is more acute. This is explained by the fact that they usually have only a small number of sectors that have become (or can become) competitive in international markets, which significantly limits prospects for their embarking on the path of growth. Under these conditions, maintaining stable development puts forward even more stringent requirements for the selection and / or formation of new competitive sectors with the aim of further moving up the chain of improving quality and creating value. And yet, the experience of countries which have successfully dealt with problems of economic lag indicates that the manufacturing sector played a significant role in this.

The results of the study can be considered as the basis for the formation of structural and industrial policies in countries of the world. A further research direction is the elaboration of methodological support for assessing progressiveness of structural transformations in the industry of countries of the world. Solving this problem will provide the opportunity for quality monitoring of the behavior of 
progressive or destructive processes occurring in the industry of world countries, which in turn will allow making timely decisions aimed at preventing a decline in economic growth of countries and deterioration in the quality of life of their people.

Author Contributions: Conceptualization, M.K.; methodology, M.K., I.G. and H.K.; validation, M.K., H.K. and V.K. (Volodymyr Korneev); formal analysis, M.K. and H.K.; investigation, M.K. and H.K.; data curation, I.G. and V.K. (Volodymyr Korneev); writing — original draft preparation, V.K. (Viktoriia Khaustova) and H.K.; writing-review and editing, M.K., I.G. and V.K. (Volodymyr Korneev); visualization, V.K. (Viktoriia Khaustova) and H.K.; supervision, M.K. All authors have read and agreed to the published version of the manuscript.

Funding: This research received no external funding.

Conflicts of Interest: The authors declare no conflict of interest.

\section{Appendix A}

Table A1. Indicators of the industrial development of the world countries in 2014 *

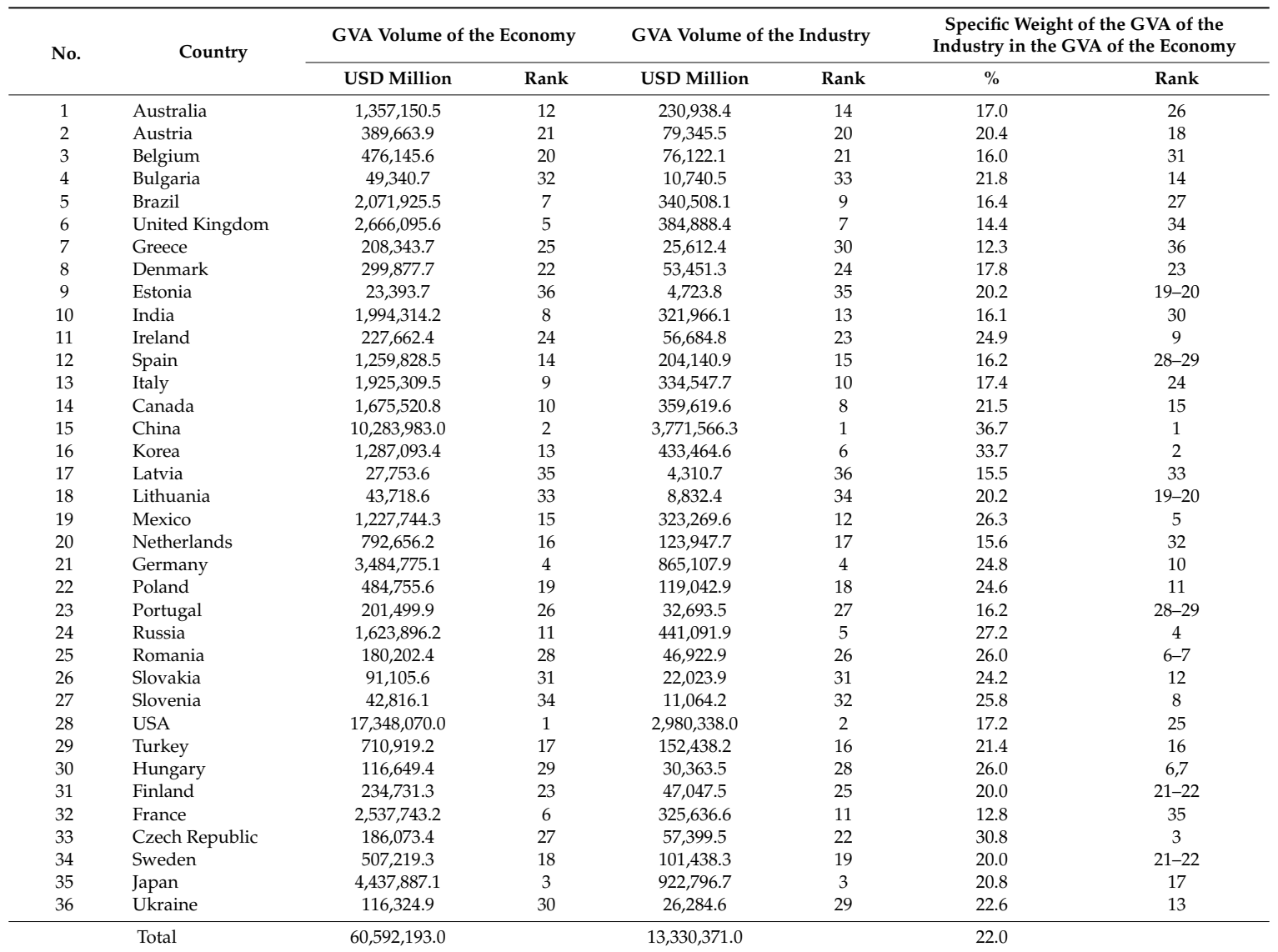

* - taking into account periodicity of formation of inter-branch balances of the world countries, the most recent period of study was 2014. Source: formed by the authors on the basis of the data [7]. 


\section{Appendix B}

Table A2. Calculation of the optimal industry structure for the manufacturing industry sector.

\begin{tabular}{|c|c|c|c|c|c|c|c|}
\hline \multirow{3}{*}{ No. } & \multirow{3}{*}{ Country } & \multicolumn{6}{|c|}{ Specific Weight of the Manufacturing Industry GVA $\left(\mathrm{SW}_{\mathrm{M}}\right)$ in the General Volume of the Industrial GVA } \\
\hline & & \multicolumn{2}{|c|}{2009 p. } & \multicolumn{2}{|c|}{$2011 \mathrm{p}}$. & \multicolumn{2}{|c|}{$2014 \mathrm{p}}$. \\
\hline & & $\%$ & Rank & $\%$ & Rank & $\%$ & Rank \\
\hline 1 & Australia & 42.52 & 36 & 36.32 & 36 & 41.97 & 36 \\
\hline 2 & Austria & 84.27 & 10 & 84.38 & 10 & 84.26 & 6 \\
\hline 3 & Belgium & 84.96 & 6 & 84.89 & 9 & 83.06 & 8 \\
\hline 4 & Bulgaria & 72.00 & 27 & 72.00 & 24 & 65.47 & 31 \\
\hline 5 & Brazil & 75.61 & 21 & 71.68 & 25 & 65.56 & 30 \\
\hline 6 & United Kingdom & 69.65 & 29 & 69.60 & 29 & 71.43 & 27 \\
\hline 7 & Greece & 75.84 & 20 & 75.84 & 22 & 71.67 & 26 \\
\hline 8 & Denmark & 73.91 & 25 & 63.65 & 32 & 73.37 & 24 \\
\hline 9 & Estonia & 71.45 & 28 & 71.45 & 26 & 71.06 & 28 \\
\hline 10 & India & 77.28 & 18 & 76.68 & 20 & 78.20 & 18 \\
\hline 11 & Ireland & 91.88 & 2 & 92.40 & 2 & 88.06 & 3 \\
\hline 12 & Spain & 81.23 & 14 & 81.05 & 14 & 76.84 & 20 \\
\hline 13 & Italy & 84.68 & 8 & 85.77 & 6 & 82.00 & 11 \\
\hline 14 & Canada & 53.37 & 35 & 63.93 & 31 & 49.64 & 35 \\
\hline 15 & China & 81.24 & 13 & 81.24 & 13 & 78.82 & 17 \\
\hline 16 & Korea & 92.39 & 1 & 93.01 & 1 & 91.09 & 1 \\
\hline 17 & Latvia & 68.92 & 30 & 68.92 & 30 & 71.86 & 25 \\
\hline 18 & Lithuania & 76.94 & 19 & 76.94 & 19 & 81.39 & 13 \\
\hline 19 & Mexico & 64.36 & 33 & 59.49 & 33 & 65.05 & 32 \\
\hline 20 & Netherlands & 67.82 & 31 & 70.35 & 28 & 70.50 & 29 \\
\hline 21 & Germany & 85.23 & 5 & 87.83 & 3 & 87.53 & 4 \\
\hline 22 & Poland & 73.74 & 26 & 71.26 & 27 & 73.82 & 23 \\
\hline 23 & Portugal & 78.84 & 16 & 78.84 & 16 & 76.67 & 21 \\
\hline 24 & Russia & 53.97 & 34 & 52.63 & 35 & 51.59 & 34 \\
\hline 25 & Romania & 85.75 & 4 & 85.75 & 7 & 77.72 & 19 \\
\hline 26 & Slovakia & 74.24 & 23 & 74.24 & 23 & 82.04 & 10 \\
\hline 27 & Slovenia & 82.66 & 12 & 82.66 & 12 & 83.43 & 7 \\
\hline 28 & USA & 74.70 & 22 & 76.16 & 21 & 73.91 & 22 \\
\hline 29 & Turkey & 78.48 & 17 & 80.40 & 15 & 80.43 & 15 \\
\hline 30 & Hungary & 83.61 & 11 & 86.84 & 5 & 87.29 & 5 \\
\hline 31 & Ukraine & 65.45 & 32 & 54.91 & 34 & 58.01 & 33 \\
\hline 32 & Finland & 84.91 & 7 & 85.26 & 8 & 82.19 & 9 \\
\hline 33 & France & 84.35 & 9 & 84.06 & 11 & 79.95 & 16 \\
\hline 34 & Czech Republic & 74.24 & 24 & 78.53 & 17 & 81.21 & 14 \\
\hline 35 & Sweden & 78.87 & 15 & 77.97 & 18 & 81.98 & 12 \\
\hline 36 & Japan & 87.24 & 3 & 87.40 & 4 & 90.55 & 2 \\
\hline \multirow{2}{*}{\multicolumn{2}{|c|}{ Average value }} & 76.32 & & 76.27 & & 75.76 & \\
\hline & & \multicolumn{6}{|c|}{76.12} \\
\hline
\end{tabular}

Source: developed by the authors based on [7]

\section{Appendix C}

Table A3. Calculation of the optimal industry structure for the Engineering TEA.

\begin{tabular}{|c|c|c|c|c|c|c|c|}
\hline \multirow{3}{*}{ No. } & \multirow{3}{*}{ Country } & \multicolumn{6}{|c|}{ Specific Weight of the Engineering TEA GVA $\left(\mathrm{SW}_{\mathrm{E}}\right)$ in the General Volume of the Industrial GVA } \\
\hline & & \multicolumn{2}{|c|}{$2009 \mathrm{p}$. } & \multicolumn{2}{|c|}{$2011 \mathrm{p}}$. & \multicolumn{2}{|c|}{2014 p. } \\
\hline & & $\%$ & Rank & $\%$ & Rank & $\%$ & Rank \\
\hline 1 & Australia & 7.93 & 36 & 6.77 & 36 & 7.81 & 35 \\
\hline 2 & Austria & 31.67 & 6 & 32.93 & 6 & 33.11 & 7 \\
\hline 3 & Belgium & 18.53 & 22 & 18.24 & 21 & 16.86 & 24 \\
\hline 4 & Bulgaria & 12.85 & 30 & 12.85 & 31 & 13.09 & 28 \\
\hline 5 & Brazil & 18.07 & 23 & 17.13 & 25 & 18.81 & 21 \\
\hline 6 & United Kingdom & 22.42 & 17 & 24.23 & 15 & 21.63 & 15 \\
\hline 7 & Greece & 7.99 & 35 & 7.99 & 35 & 6.18 & 36 \\
\hline 8 & Denmark & 27.93 & 10 & 23.38 & 16 & 21.80 & 14 \\
\hline 9 & Estonia & 17.39 & 25 & 17.39 & 24 & 16.75 & 25 \\
\hline 10 & India & 19.73 & 20 & 20.68 & 19 & 17.30 & 23 \\
\hline 11 & Ireland & 19.66 & 21 & 17.98 & 22 & 10.05 & 31 \\
\hline 12 & Spain & 20.06 & 19 & 19.28 & 20 & 19.74 & 17 \\
\hline 13 & Italy & 27.82 & 11 & 28.54 & 11 & 26.80 & 10 \\
\hline 14 & Canada & 14.94 & 27 & 21.43 & 18 & 13.82 & 27 \\
\hline 15 & China & 26.55 & 15 & 26.55 & 14 & 26.45 & 11 \\
\hline 16 & Korea & 48.45 & 1 & 49.59 & 1 & 47.40 & 1 \\
\hline 17 & Latvia & 9.87 & 34 & 9.87 & 34 & 9.51 & 34 \\
\hline 18 & Lithuania & 12.16 & 32 & 12.16 & 32 & 9.71 & 33 \\
\hline 19 & Mexico & 15.26 & 26 & 16.42 & 28 & 19.56 & 19 \\
\hline 20 & Netherlands & 14.87 & 28 & 16.85 & 26 & 19.32 & 20 \\
\hline 21 & Germany & 43.76 & 2 & 46.31 & 3 & 44.48 & 2 \\
\hline
\end{tabular}


Table A3. Cont.

\begin{tabular}{|c|c|c|c|c|c|c|c|}
\hline \multirow{3}{*}{ No. } & \multirow{3}{*}{ Country } & \multicolumn{6}{|c|}{ Specific Weight of the Engineering TEA GVA $\left(\mathrm{SW}_{\mathrm{E}}\right)$ in the General Volume of the Industrial GVA } \\
\hline & & \multicolumn{2}{|c|}{$2009 \mathrm{p}$. } & \multicolumn{2}{|c|}{$2011 \mathrm{p}}$. & \multicolumn{2}{|c|}{$2014 \mathrm{p}}$. \\
\hline & & $\%$ & Rank & $\%$ & Rank & $\%$ & Rank \\
\hline 22 & Poland & 20.36 & 18 & 15.95 & 29 & 17.63 & 22 \\
\hline 23 & Portugal & 17.71 & 24 & 17.71 & 23 & 12.54 & 29 \\
\hline 24 & Russia & 10.59 & 33 & 10.23 & 33 & 9.81 & 32 \\
\hline 25 & Romania & 22.45 & 16 & 22.45 & 17 & 19.58 & 18 \\
\hline 26 & Slovakia & 27.11 & 13 & 27.11 & 12 & 31.68 & 8 \\
\hline 27 & Slovenia & 26.99 & 14 & 26.99 & 13 & 24.46 & 13 \\
\hline 28 & USA & 27.72 & 12 & 28.58 & 10 & 24.79 & 12 \\
\hline 29 & Turkey & 14.42 & 29 & 14.77 & 30 & 14.21 & 26 \\
\hline 30 & Hungary & 40.63 & 3 & 46.93 & 2 & 40.35 & 3 \\
\hline 31 & Ukraine & 12.76 & 31 & 16.64 & 27 & 11.54 & 30 \\
\hline 32 & Finland & 33.07 & 4 & 30.34 & 8 & 31.05 & 9 \\
\hline 33 & France & 29.04 & 9 & 28.88 & 9 & 21.35 & 16 \\
\hline 34 & Czech Republic & 32.11 & 5 & 35.81 & 4 & 37.97 & 4 \\
\hline 35 & Sweden & 30.51 & 8 & 34.00 & 5 & 35.37 & 5 \\
\hline 36 & Japan & 31.09 & 7 & 31.14 & 7 & 34.73 & 6 \\
\hline \multirow{2}{*}{\multicolumn{2}{|c|}{ Average value }} & 22.91 & & 23.36 & & 22.16 & \\
\hline & & \multicolumn{6}{|c|}{22.81} \\
\hline
\end{tabular}

Source: developed by the authors based on [7].

\section{Appendix D}

Table A4. Indicators of progressiveness of the world countries industrial structure by various sectoral divisions in 2014.

\begin{tabular}{|c|c|c|c|c|c|c|c|}
\hline \multirow[t]{2}{*}{ No. } & \multirow[t]{2}{*}{ Country } & \multicolumn{2}{|c|}{$\begin{array}{l}\text { Specific Weight of the } \\
\text { Manufacturing Industry GVA } \\
\left(\mathrm{SW}_{\mathrm{M}}\right) \text { in the General Volume of } \\
\text { the Industrial GVA }\end{array}$} & \multicolumn{2}{|c|}{$\begin{array}{c}\text { Specific Weight of the } \\
\text { High-Technology Sector GVA } \\
\text { (SW } \\
\text { HTS }) \text { in the General Volume of } \\
\text { the Industrial GVA }\end{array}$} & \multicolumn{2}{|c|}{$\begin{array}{l}\text { Specific Weight of the } \\
\text { ENGINEERING TEA GVA (SW }) \\
\text { in the General Volume of the } \\
\text { Industrial GVA }\end{array}$} \\
\hline & & $\%$ & Rank & $\%$ & Rank & $\%$ & Rank \\
\hline 1 & Australia & 41.97 & 36 & 13.41 & 35 & 7.81 & 35 \\
\hline 2 & Austria & 84.26 & 6 & 43.90 & 10 & 33.11 & 7 \\
\hline 3 & Belgium & 83.06 & 8 & 44.30 & 9 & 16.86 & 24 \\
\hline 4 & Bulgaria & 65.47 & 31 & 22.51 & 28 & 13.09 & 28 \\
\hline 5 & Brazil & 65.56 & 30 & 30.42 & 21 & 18.81 & 21 \\
\hline 6 & United Kingdom & 71.43 & 27 & 35.41 & 18 & 21.63 & 15 \\
\hline 7 & Greece & 71.67 & 26 & 12.70 & 36 & 6.18 & 36 \\
\hline 8 & Denmark & 73.37 & 24 & 46.35 & 7 & 21.80 & 14 \\
\hline 9 & Estonia & 71.06 & 28 & 22.38 & 29 & 16.75 & 25 \\
\hline 10 & India & 78.20 & 18 & 30.09 & 22 & 17.30 & 23 \\
\hline 11 & Ireland & 88.06 & 3 & 42.27 & 12 & 10.05 & 31 \\
\hline 12 & Spain & 76.84 & 20 & 33.30 & 20 & 19.74 & 17 \\
\hline 13 & Italy & 82.00 & 11 & 38.43 & 15 & 26.80 & 10 \\
\hline 14 & Canada & 49.64 & 35 & 20.20 & 31 & 13.82 & 27 \\
\hline 15 & China & 78.82 & 17 & 37.08 & 17 & 26.45 & 11 \\
\hline 16 & Korea & 91.09 & 1 & 60.71 & 1 & 47.40 & 1 \\
\hline 17 & Latvia & 71.86 & 25 & 16.84 & 32 & 9.51 & 34 \\
\hline 18 & Lithuania & 81.39 & 13 & 24.82 & 26 & 9.71 & 33 \\
\hline 19 & Mexico & 65.05 & 32 & 28.10 & 24 & 19.56 & 19 \\
\hline 20 & Netherlands & 70.50 & 29 & 34.89 & 19 & 19.32 & 20 \\
\hline 21 & Germany & 87.53 & 4 & 58.77 & 2 & 44.48 & 2 \\
\hline 22 & Poland & 73.82 & 23 & 29.01 & 23 & 17.63 & 22 \\
\hline 23 & Portugal & 76.67 & 21 & 21.93 & 30 & 12.54 & 29 \\
\hline 24 & Russia & 51.59 & 34 & 15.22 & 34 & 9.81 & 32 \\
\hline 25 & Romania & 77.72 & 19 & 25.91 & 25 & 19.58 & 18 \\
\hline 26 & Slovakia & 82.04 & 10 & 41.87 & 13 & 31.68 & 8 \\
\hline 27 & Slovenia & 83.43 & 7 & 46.51 & 6 & 24.46 & 13 \\
\hline 28 & USA & 73.91 & 22 & 39.39 & 14 & 24.79 & 12 \\
\hline 29 & Turkey & 80.43 & 15 & 23.75 & 27 & 14.21 & 26 \\
\hline 30 & Hungary & 87.29 & 5 & 56.05 & 3 & 40.35 & 3 \\
\hline 31 & Ukraine & 58.01 & 33 & 16.40 & 33 & 11.54 & 30 \\
\hline 32 & Finland & 82.19 & 9 & 42.60 & 11 & 31.05 & 9 \\
\hline 33 & France & 79.95 & 16 & 37.53 & 16 & 21.35 & 16 \\
\hline 34 & Czech Republic & 81.21 & 14 & 48.93 & 4 & 37.97 & 4 \\
\hline 35 & Sweden & 81.98 & 12 & 48.63 & 5 & 35.37 & 5 \\
\hline 36 & Japan & 90.55 & 2 & 45.61 & 8 & 24.73 & 6 \\
\hline \multicolumn{2}{|c|}{ Average value } & 75.76 & & 34.85 & & 22.16 & \\
\hline
\end{tabular}

Source: developed by the authors based on [7]. 


\section{Appendix E}

Table A5. Input data for calculation and value of the indicator of correspondence of the industrial structure of the world countries with its progressive state in 2014.

\begin{tabular}{|c|c|c|c|c|c|c|c|}
\hline \multirow{2}{*}{ No. } & \multirow{2}{*}{ Country } & \multicolumn{2}{|c|}{$\begin{array}{l}\text { GVA per Capita, USD } \\
\text { (at Current Prices) }\end{array}$} & \multicolumn{2}{|c|}{$\begin{array}{l}\text { Human Development } \\
\text { Index (HDI) }\end{array}$} & \multicolumn{2}{|c|}{$\mathrm{I}_{\mathrm{PS}}$} \\
\hline & & Value & Rank & Value & Rank & Value & Rank \\
\hline 1 & Australia & $62,403.1$ & 2 & 0.935 & 1 & 0.4987 & 36 \\
\hline 2 & Austria & $51,717.5$ & 7 & 0.885 & 14 & 1.2999 & 8 \\
\hline 3 & Belgium & $47,355.3$ & 11 & 0.890 & 12 & 1.0526 & 12 \\
\hline 4 & Bulgaria & $7,864.8$ & 33 & 0.782 & 30 & 0.7541 & 28 \\
\hline 5 & Brazil & $12,026.6$ & 30 & 0.755 & 33 & 0.8095 & 24 \\
\hline 6 & United Kingdom & $46,967.7$ & 12 & 0.907 & $8-9$ & 0.9934 & 18 \\
\hline 7 & Greece & $21,761.0$ & 20 & 0.865 & 20 & 0.6916 & 31 \\
\hline 8 & Denmark & $62,549.0$ & 1 & 0.923 & 2 & 1.0309 & 16 \\
\hline 9 & Estonia & $20,247.2$ & 21 & 0.861 & 21 & 0.8482 & 23 \\
\hline 10 & India & 576.0 & 36 & 0.609 & 36 & 0.8869 & 22 \\
\hline 11 & Ireland & $55,628.2$ & 4 & 0.916 & $4-5$ & 0.7978 & 26 \\
\hline 12 & Spain & $29,623.2$ & 16 & 0.876 & 17 & 0.9984 & 17 \\
\hline 13 & Italy & $35,396.7$ & 15 & 0.873 & 18 & 1.1442 & 11 \\
\hline 14 & Canada & $50,633.2$ & 8 & 0.913 & 7 & 0.6720 & 33 \\
\hline 15 & China & $7,683.5$ & 34 & 0.674 & 5 & 0.727 & 35 \\
\hline 16 & Korea & $27,811.4$ & 17 & 0.898 & 10 & 1.7115 & 1 \\
\hline 17 & Latvia & $15,716.4$ & 25 & 0.819 & 27 & 0.6796 & 32 \\
\hline 18 & Lithuania & $16,545.1$ & 24 & 0.839 & 24 & 0.7250 & 30 \\
\hline 19 & Mexico & $10,582.4$ & 31 & 0.756 & 32 & 0.7980 & 25 \\
\hline 20 & Netherlands & 52,830 & 6 & 0.922 & 3 & 0.9082 & 21 \\
\hline 21 & Germany & $48,142.8$ & 10 & 0.916 & $4-5$ & 1.6249 & 2 \\
\hline 22 & Poland & $14,345.2$ & 26 & 0.843 & 23 & 0.9193 & 19 \\
\hline 23 & Portugal & $22,077.5$ & 19 & 0.830 & 25 & 0.7675 & 27 \\
\hline 24 & Russia & $14,125.9$ & 28 & 0.798 & 28 & 0.6246 & 35 \\
\hline 25 & Romania & $10,027.0$ & 32 & 0.793 & 29 & 0.5181 & 20 \\
\hline 26 & Slovakia & $18,629.8$ & 23 & 0.844 & 22 & 1.3070 & 7 \\
\hline 27 & Slovenia & $24,202.4$ & 18 & 0.880 & 16 & 1.2255 & 10 \\
\hline 28 & USA & $55,033.0$ & 5 & 0.915 & 5 & 1.0526 & 13 \\
\hline 29 & Turkey & $12,127.5$ & 29 & 0.761 & 31 & 0.7441 & 29 \\
\hline 30 & Hungary & $14,197.8$ & 27 & 0.828 & 26 & 1.5153 & 3 \\
\hline 31 & Ukraine & $3,104.7$ & 35 & 0.747 & 34 & 0.6705 & 34 \\
\hline 32 & Finland & $49,914.6$ & 9 & 0.883 & 15 & 1.2347 & 9 \\
\hline 33 & France & $43,008.7$ & 13 & 0.888 & 13 & 1.0436 & 14 \\
\hline 34 & Czech Republic & $19,744.6$ & 22 & 0.870 & 19 & 1.4332 & 4 \\
\hline 35 & Sweden & $59,241.6$ & 3 & 0.907 & $8-9$ & 1.3718 & 5 \\
\hline \multirow[t]{2}{*}{36} & Japan & $38,109.4$ & 14 & 0.891 & 11 & 1.3361 & 6 \\
\hline & Average value & $30,541.6$ & & 0.848 & & 0.9838 & \\
\hline
\end{tabular}

\section{References}

1. Jorgenson, D.W.; Timmer, M. Structural Change in Advanced Nations: A New Set of Stylised Facts. Scand. J. Econ. 2011, 113, 1-29. [CrossRef]

2. Rodrik, D. Unconditional Convergence in Manufacturing. Q. J. Econ. 2013, 128, 165-204. [CrossRef]

3. Rocha, I.L. Manufacturing as driver of economic growth. PSL Q. Rev. 2018, 71, 103-138. [CrossRef]

4. Khaustova, V.Y. Industrial Policy in Ukraine: Formation and Forecasting; INZHEK PH: Kharkiv, Ukraine, 2015; ISBN 978-966-392-143-3. Available online: https://www.researchgate.net/publication/ 335919701_Promislova_politika_v_Ukraini_formuvanna_ta_prognozuvanna_INDUSTRIAL_POLICY_IN_ UKRAINE_FORMATION_AND_FORECASTING (accessed on 9 January 2020).

5. Kyzym, M.O.; Khaustova, V.Y.; Kramarev, H.V. Substantiation of perspective directions of development of Ukrainian manufacturing industry. Probl. Econ. 2019, 1, 28-45. [CrossRef]

6. Agenda Item 3-Adaptation of Industrial policy to the digital world for economic diversification and structural transformation. In Proceedings of the Multi-year Expert Meeting on Better Economic Conditions at All Levels in Support of Inclusive and Sustainable Development and Promotion of Economic Integration and Cooperation, Geneva, Switzerland, 19-20 March 2018; Trade and Development Commission. Available online: https://unctad.org/en/pages/MeetingDetails.aspx?meetingid=1693 (accessed on 1 February 2020).

7. World Input-Output Database. Available online: http://www.wiod.org/home (accessed on 27 November 2019).

8. Fritsch, M. Theory of economic development. An Inquiry into Profits, Capital, Credit, Interest, and the Business Cycle. Reg. Studies 2017, 51, 654-655. [CrossRef] 
9. Fisher, A. The Clash of Progress and Security; Macmillan: London, UK, 1935.

10. Clark, C. The Conditions of Economic Progress; Macmillan: London, UK, 1940.

11. Fourastie, J. Predicting Economic Changes in Our Time. Diogenes 1954, 2, 14-38. [CrossRef]

12. Rosenstein-Rodan, P.N. Problems of industrialization of Eastern and South-Eastern Europe. Econ. J. 1943, 53, 202-211. [CrossRef]

13. Nurkse, R. Problems of Capital Formation in Underdeveloped Countries; Basil Blackwell: Oxford, UK, 1953.

14. Lewis, A. Economic Development with Unlimited Supplies of Labour. Manchester Sch. 1954, 22, $139-191$. [CrossRef]

15. Ranis, G.; Fei, J.C.H. A Theory of Economic Development. Am. Econ. Rev. 1961, 51, 533-565.

16. Chenery, H.; Watanabe, T. International Comparisons of the Structure of Production. JSTOR Econom. 1958, 26, 487-521. Available online: http://www.jstor.org/stable/1907514 (accessed on 20 November 2019). [CrossRef]

17. Hirschman, A. Interregional and International Transmission of Economic Growth. The Strategy of Economic Development; Norton: Nueva York, NY, USA, 1958.

18. Hoffman, W.G. The Growth of Industrial Economics; Manchester University Press: Manchester, UK, 1958.

19. Kuznets, S. Modern Economic Growth: Rate, Structure and Spread; Yale University Press: New Haven, CT, USA, 1966.

20. Todaro, M.P. A model of labor migration and urban unemployment in less developed countries. Am. Econ. Rev. 1969, 59, 138-149.

21. Todaro, M.P.; Smith, S.C. Economic Development; Addison-Wesley: Boston, MA, USA, 2009.

22. Chenery, H.; Syrquin, M. Patterns of Development, 1950-1970; Oxford University Press: Londres, UK, 1975.

23. Chenery, H.; Syrquin, M. A Comparative Analysis of Industrial Growth. In Economic Growth and Resources; Matthews, R.C.O., Ed.; International Economic Association Series; Palgrave Macmillan: London, UK, 1980. [CrossRef]

24. Ishikawa, S. Structural Change. In The New Palgrave: A Dictionary of Economics; Eatwell, J., Milgate, M., Newman, P., Eds.; Springer: London, UK, 1987; pp. 523-525. [CrossRef]

25. Raiser, M.; Schaffer, M.; Schuchhardt, J. Benchmarking Structural Change in Transition; Working paper, 79; European Bank for Reconstruction and Development: London, UK, 2003.

26. Thießen, U.; Gregory, P.R. Modelling the Structural Change of Transition Countries; Institute for Economic Research: DIW Berlin, Germany, 2005.

27. Kyzym, M.O.; Milyutin, H.V. The Structural Changes in the Economy of Ukraine and its Energy Intensity. Bus. Inform. 2017, 12, 132-143. Available online: https://www.business-inform.net/search/?qu=KYZYM\&x= $0 \& y=0$ (accessed on 20 November 2019).

28. Gryshova, I.; Shabatura, T.; Girdzijauskas, S.; Streimikiene, D.; Ciegis, R.; Griesiene, I. The Paradox of Value and Economic Bubbles: New Insights for Sustainable Economic Development. Sustainability 2019, 11, 6888. [CrossRef]

29. Beg, M.; Basarac Sertic, M.; Druzic, I. Determinants of Deindustrialization in Developed European and Post-Communist Countries. Monten. J. Econo. 2017, 13, 93-106. [CrossRef]

30. Dudzevičiūtè, G.; Mačiulis, A.; Tvaronavičienè, M. Structural Changes of Economies: Lithuania in the Global Context. Technol. Econo. Dev. Econ. 2014, 20, 353-370. [CrossRef]

31. Teigeiro, L.R.; Solis, J.S. Coefficient stability and structural change in the Spanish economy. Econ. Chang. Restruct. 2007, 40, 387-409. [CrossRef]

32. Alba, L.-L. Structural changes and convergence in EU and in Adriatic-Balkans region. ERSA Conference Papers; European Regional Science Association, 2011. Available online: http://revecon.ro/articles/2011-1/2011-1-5.pdf (accessed on 15 November 2019).

33. Jiang, Y. Structural change and growth in China under economic reforms: Patterns, causes and implications. Rev. Urban Regional Dev. Studies 2011, 23, 48-65. [CrossRef]

34. Mao, R.; Yao, Y. Structural change in small open economy: An application to South Korea. Pac. Econ. Rev. 2012, 17, 29-56.

35. Zdrazil, P.; Kraftova, I.; Mateja, Z. Reflection of Industrial Structure in Innovative Capability. Inz. Ekon. Eng. Econ. 2016, 27, 304-315. [CrossRef]

36. Tanuwidjaja, E.; Thangavelu, S. Structural change and productivity growth in the Japanese manufacturing industry. Global Econ. Rev. 2007, 36, 385-405. 
37. Matsuyama, K. Structural change in an interdependent world: A global view of manufacturing decline. J. Eur. Econ. Association 2009, 7, 478-486. [CrossRef]

38. Kokocinska, M.; Puziak, M. Structural Changes in the Economy in the Light of the Neoclassical Approach. A Case Study: Spain and Poland. Rev. Econ. Mund. 2009, 21, 169-193. Available online: http://www.redalyc. org/articulo.oa?id=86611886007 (accessed on 20 January 2020).

39. Cho, B.-S.; Cho, S.S.; Lee, J. An Alternative Approach of Input-Output Tables to Dynamic Structure Changes in Korean IT Industries. Technol. Econ. Dev. Econ. 2013, 19, 257-271. [CrossRef]

40. Gryshova, I.; Petrova, M.; Tepavicharova, M.; Diachenko, A.P.; Gutsul, T. A model for selection of a management team to ensure the sustainability and development of the business organizations. Entrepreneurship Sustain. 2019, 7, 690-703. [CrossRef]

41. Noguera-Méndez, P.; Semitiel-García, M.; Lypez-Martínez, M. Estructura interindustrialy desarrollo económico. Un análisis desde las perspectivas de redese input-output (Interindustrial Structure and Economic Development. An Analysis from Network and Input-Output Perspectives). Trimest. Econ. 2016, 331, 581-609. [CrossRef]

42. Kamaruddin, R.; Masron, T.A. Sources of Growth in the Manufacturing Sector in Malaysia: Evidence from ARDL AND Structural Decomposition Analyses. Asian Acad. Manag. J. 2010, 15, 99-116.

43. Olczyk, M.; Kordalska, A. Growth and Structural Changes in Transition Countries: The Chicken or the Egg? J. Bus. Econ. Manag. 2018, 19, 544-565. [CrossRef]

44. Human Development Index (HDI). Human Development Reports. Available online: http://hdr.undp.org/en/ content/human-development-index-hdi (accessed on 20 November 2019).

45. Kyzym, M.O.; Kushnaryov, E.P. The Level and Quality of Life of the Population; INZHEK PH: Kharkiv, Ukraine, 2004; 272p, ISBN 966-8515-55-2. Available online: https://www.researchgate.net/publication/ 337943482_Riven_i_akist_zitta_naselenna_The_level_and_quality_of_life_of_the_population (accessed on 7 February 2020).

46. Iacobuta, A.O.; Mursa, G.C.; Mihai, C.; Cautisanu, C.; Cismas, L.M. Institutions and sustainable development: A cross-country analyses. Transform. Bus. Econ. 2019, 18, 628-646.

47. Jednak, S.; Kragulj, D.; Bulajic, M. A comparative analyses of development in Southeast European countries. Technol. Econ. Dev. Econ. 2018, 24, 253-270. [CrossRef]

48. New Philosophy Encyclopedia; Mysl: Moscow, Russia, 2010.

49. Modern Economic Dictionary; INFRA-M: Moscow, Russia, 1999.

50. Gasanov, M.A. Influence of technological changes on structural transformations of the world and Russian economies. Ekonomika 2009, 3, 239-243.

51. Trifonov, Y.V.; Veselova, N.V. Methodological approaches to the analysis of the structure of economy at the regional level. Issues Stat. 2015, 2, 37-49.

52. Khaustova, V.Y.; Kramarev, H.V.; Yaroshenko, I.V. Theoretical grounds of the structural changes in the economy. Bus. Inform. 2017, 12, 24-37. Available online: https://www.business-inform.net/search/?qu= Khaustova\&x $=0 \& y=0$ (accessed on 20 November 2019).

53. Ozhegov, S.I.; Shvedova, N.Y. The Russian Language Definition Dictionary; Azbukovnik: Moscow, Russia, 1998; 944p.

54. Pirog, O.V. Adaptation of the structure of the national economy of Ukraine to the requirements of the post-industrial society. J. Lviv Polytech. Natl. Univ. Probl. Econ. Manag. 2011, 698, 98-103.

55. Akayeva, A.A.; Sokolov, V.N. About industrial and technological structural changes necessary for modernization of the Russian economy. MIR (Modernization. Innovation. Research) 2016, 7, 38-48. Available online: https://www.mir-nayka.com/jour/article/view/385 (accessed on 3 February 2020). [CrossRef]

56. UNIDO. Industrial Development Report 2016. Available online: https://www.unido.org/sites/default/files/ 2015-12/EBOOK_IDR2016_FULLREPORT_0.pdf (accessed on 1 February 2020).

57. Davydov, A.A. Modular Analysis and Construction of Society; Russian Academy of Sciences: Moscow, Russia, 1994.

(C) 2020 by the authors. Licensee MDPI, Basel, Switzerland. This article is an open access article distributed under the terms and conditions of the Creative Commons Attribution (CC BY) license (http://creativecommons.org/licenses/by/4.0/). 